\title{
CO Release from N,C,S-Pincer Iron(III) Carbonyl Complexes Induced by Visible-to-NIR Light Irradiation: Mechanistic Insight into Effects of Axial Phosphorus Ligands
}

Toyotaka Nakae, Masakazu Hirotsu, Hiroshi Nakajima

\begin{tabular}{|c|l|}
\hline Citation & Inorganic Chemistry, 57(14); 8615-8626 \\
\hline Issue Date & 2018-06-29 \\
\hline Type & Journal Article \\
\hline Textversion & Author \\
\hline Rights & $\begin{array}{l}\text { This document is the Accepted Manuscript version of a Published Work that appeared } \\
\text { in final form in Inorganic Chemistry, copyright } @ \text { American Chemical Society after peer } \\
\text { review and technical editing by the publisher. To access the final edited and published } \\
\text { work see https://doi.org/10.1021/acs.inorgchem.8b01407 }\end{array}$ \\
\hline DOI & \begin{tabular}{l} 
10.1021/acs.inorgchem.8b01407 \\
\hline
\end{tabular} \\
\hline
\end{tabular}

Self-Archiving by Author(s)

Placed on: Osaka City University

Toyotaka Nakae, Masakazu Hirotsu, Hiroshi Nakajima. (2018). CO Release from N,C,S-Pincer Iron(III) Carbonyl Complexes Induced by Visible-to-NIR Light Irradiation: Mechanistic Insight into Effects of Axial Phosphorus Ligands. Inorganic Chemistry. 57, 8615-8626.

https://doi.org/10.1021/acs.inorgchem.8b01407. 


\section{CO Release from $N, C, S$-Pincer Iron(III) Carbonyl}

\section{Complexes Induced by Visible-to-NIR-Light}

\section{Irradiation: Mechanistic Insight into Effects of Axial}

\section{Phosphorus Ligands}

Toyotaka Nakae, Masakazu Hirotsu, ${ }^{*}$ and Hiroshi Nakajima*

Division of Molecular Materials Science, Graduate School of Science, Osaka City University, 33-138 Sugimoto, Sumiyoshi-ku, Osaka 558-8585, Japan

KEYWORDS: Photo-inducible CO-releasing molecules; N,C,S-pincer complexes; Iron carbonyl complexes; Near infrared light

ABSTRACT: Light-induced CO release from newly synthesized N,C,S-pincer iron(III) carbonyl complexes with two phosphorus ligands-trans- $\left[\mathrm{Fe}\left(\mathrm{L}-\kappa^{3} N, C, S\right)(\mathrm{CO})\left(\mathrm{PR}_{2} \mathrm{R}^{\prime}\right)_{2}\right] \mathrm{PF}_{6}\left([1] \mathrm{PF}_{6}, \mathrm{R}=\right.$ $\mathrm{Me}, \mathrm{R}^{\prime}=\mathrm{Ph} ;[2] \mathrm{PF}_{6}, \mathrm{R}=\mathrm{R}^{\prime}=\mathrm{Me} ;[3] \mathrm{PF}_{6}, \mathrm{R}=\mathrm{R}^{\prime}=\mathrm{OEt}$ )—were investigated. All the iron(III) carbonyl complexes were stable in solution and showed light-inducible CO release under ambient conditions. Studies on the wavelength dependence of photoreaction revealed that the phosphite complex $[3] \mathrm{PF}_{6}$ exhibited the most extended photosensitivity including all visible and a part of near-IR light (390 - $800 \mathrm{~nm}$ wavelengths). The phosphine complexes [1] $\mathrm{PF}_{6}$ and [2] $\mathrm{PF}_{6}$ showed sensitivity to only the higher energy region of visible light (390 - $450 \mathrm{~nm})$. Quantum 
chemical calculations and spectroscopic data suggested that all complexes $[\mathbf{1}] \mathrm{PF}_{6}-[\mathbf{3}] \mathrm{PF}_{6}$ have $\mathrm{d} \pi-\mathrm{d} \pi$ excitation modes to depopulate $\mathrm{Fe}-\mathrm{C}$ (carbonyl) bonding and potentially induce the $\mathrm{CO}$ release by irradiation of light in the near-IR region, although moderately weakened Fe$\mathrm{C}$ (carbonyl) bonding due to stronger $\pi$-backbonding by the phosphite ligand rendered the excitation effective on the $\mathrm{CO}$ release exclusively in $[3] \mathrm{PF}_{6}$.

\section{INTRODUCTION}

Carbon monoxide (CO) is a well-known toxic gas that has strong binding ability to the iron center of heme, which inhibits the delivery of $\mathrm{O}_{2}$ by hemoglobin and ATP synthesis by cytochrome oxidases. ${ }^{1,2} \mathrm{CO}$ is produced in mammalian cells via heme catabolism by inducible and constitutive heme oxygenases. In the past few decades, endogenously produced $\mathrm{CO}$ has been revealed to be an important signaling molecule accompanied by other heme degradation products $^{3-7}$ to exert physiological and pathological functions such as anti-inflammation, vascular expansion, and anti-apoptotic and anti-proliferative activity, which motivate researchers to apply $\mathrm{CO}$ as a therapeutic agent (CO therapy) ${ }^{8-10}$ In addition, a recent report on the role of CO in sleep apnea supposes that there are still unveiled functions of $\mathrm{CO}$, which may extend the potential use of CO to other therapeutic areas. ${ }^{11}$ Inhalation is a simple and direct method of introducing CO to a living body, while difficulties in secure delivery and controlled release of CO to a target site are major problems of this method and hinder rapid development of CO therapy in basic medicine and in clinical research sectors. To address these problems, CORMs, which are typically metal carbonyl complexes, have been developed. ${ }^{11-17}$ Among the various types of CORMs, photoresponsive metal carbonyl complexes help achieve target-specific release of CO at a desired site and timing in a quantitative manner depending on the irradiation time. Although photo-induced CO-elimination is the fundamental reaction of metal carbonyl complexes, a 
limited number of carbonyl complexes are applicable to photoinducible CORMs (photoCORMs), as the efficient wavelength for $\mathrm{CO}$ elimination is generally restricted to either the ultraviolet (UV) or short wavelength regions of visible light. ${ }^{18-22}$ Irradiation of UV light to living cells is a possible cause for genetic mutation and consequent cytotoxicity. Visible light of shorter wavelengths is also not suitable for activating photoresponsive molecules in vivo because of the intense absorption of this light by biological components such as heme species. ${ }^{23}$ The ideal wavelength for light to release $\mathrm{CO}$ is limited to the range $650-1000 \mathrm{~nm}$, which is the most transparent region of biological tissue and is referred to as the phototherapeutic window. ${ }^{23}$ The shift in wavelength to the longer side suitable for phototherapy is one of the major challenges in developing photo-CORMs for physiological application. ${ }^{24-26}$

Recent studies on monovalent-manganese-based photo-CORMs have established a molecular design to impart responsiveness to long-wavelength light (500 nm to NIR), which utilizes MLCT excited states. $^{27,28}$ Photo-CORMs free of transition metals have also been reported. ${ }^{29}$ Welldesigned boron-dipyrromethene (BODIPY)-based photo-CORMs show photosensitivity to visible-to-NIR light. ${ }^{29}$ However, these photo-CORMs have problems that make them unfit for therapeutic use. High Mn concentration could be a cause of neurological disorders, termed "manganism", ${ }^{30-33}$ and the CO-releasing efficiency of BODIPY-based photo-CORMs is airsensitive due to its CO-releasing mechanism via the triplet excited state, which could be quenched by molecular oxygen under ambient conditions. ${ }^{29}$

An iron-carbonyl complex is a promising choice to settle these problems. Mammals possess iron regulatory systems that respond to the abundance of iron ions in the body. ${ }^{34-36}$ This reduces the risk of free iron ions being produced after CO release from CORM. ${ }^{37-43}$ The iron(II) carbonyl complex with cysteamine ligands cis- $\left[\mathrm{Fe}(\mathrm{CO})_{2}\left(\mathrm{NH}_{2} \mathrm{CH}_{2} \mathrm{CH}_{2} \mathrm{~S}\right)_{2}\right]$ (CORM-S1) was the first 
reported iron-based photo-CORM activated by visible light. The effective wavelength for CO release from this complex was reported to be $470 \mathrm{~nm}$ at the longest. ${ }^{37-40}$ The construction of an iron-based photo-CORM responsive to long-wavelength light has been achieved by the combination of conservative iron(0) and iron(II) carbonyl complexes with NIR-responsive materials such as a photon upconversion system, NIR-inducible heater, or Prussian blue. ${ }^{44,45}$ In terms of the combination with materials responsive to other bio-permeable external stimuli, carbonyl complexes combined with magnetically heatable nano-particles have been recently reported. $^{46,47}$

However, the molecular design of iron-based photo-CORMs immediately responsive to light in the phototherapeutic window is still challenging. This is possibly due to the large ligand-field splitting of $\mathrm{d} \pi$ and $\mathrm{d} \sigma^{*}$ orbitals in low-oxidation-states associated with photoinduced CO dissociation from iron carbonyl complexes. ${ }^{18-20}$

We recently reported the synthesis and properties of a novel iron complex with an $N, C, S$ tridentate ligand, trans $-\left[\mathrm{Fe}(\mathrm{PyBPT})(\mathrm{CO})\left(\mathrm{PMe}_{2} \mathrm{Ph}\right)_{2}\right] \mathrm{PF}_{6}\left([\mathbf{1}] \mathrm{PF}_{6}\right)$, where PyBPT is a doubly deprotonated form of 3'-(2''-pyridyl)-1,1'-biphenyl-2-thiol formed via the C-S bond cleavage of the dibenzothiophene derivative. ${ }^{48-51}$ The $N, C, S$-pincer iron(III) carbonyl complex exhibited unusual stability in solution under ambient conditions in the dark, while the CO ligand readily underwent substitution reaction with the coordinative solvent in response to the short wavelength region of visible light. ${ }^{52}$ A theoretical study indicated that SOMO of the iron(III) carbonyl complex mainly consisted of the $\mathrm{d} \pi$ orbital of the central iron and $\mathrm{p} \pi$ orbital of the sulfur atom. The participation of $\mathrm{Fe}-\mathrm{CO} \pi$-backbonding in the SOMO was negligible. A possible mechanism could be inferred from these results for the release of $\mathrm{CO}$ in response to light, different from that for iron(0) and iron(II) carbonyl complexes; excitations from low-lying bonding $\mathrm{d} \pi(\mathrm{Fe}-\mathrm{CO})$ 
orbitals to singly occupied $\mathrm{d} \pi$ orbital, corresponding to $\mathrm{d}_{\mathrm{zx}}-\mathrm{d}_{\mathrm{xy}}$ and $\mathrm{d}_{\mathrm{yz}}-\mathrm{d}_{\mathrm{xy}}$ excitations (Figure 1). However, $[\mathbf{1}] \mathrm{PF}_{6}$ exhibited similar photosensitivity to conventional iron(0) and iron(II) carbonyl complexes in terms of light wavelength for the release of CO (400 nm at longest). The SOMO of $[1] \mathrm{PF}_{6}$ has a $\pi$-backbonding interaction from iron to phosphorus $\sigma^{*}(\mathrm{P}-\mathrm{C})$ orbitals. Therefore, replacement of axial phosphine ligands affected the SOMO energy level of the complex, resulting in modulation of the energy gap corresponding to excitation from $\mathrm{d} \pi(\mathrm{Fe}-\mathrm{CO})$ to SOMO.

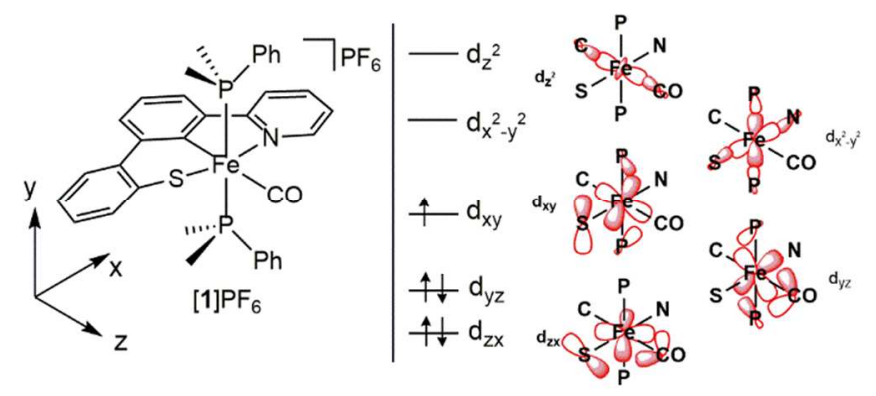

Figure 1. Schematic views of energy diagram and orbitals in the vicinity of SOMO calculated for the iron(III) carbonyl complex, $[1] \mathrm{PF}_{6}{ }^{52}$

Here, we report the effect of axial phosphite ligands on the photosensitivity of the iron(III) carbonyl complex. Simple replacement of axial phosphine $\left(\mathrm{PMe}_{2} \mathrm{Ph}\right)$ ligands with triethyl phosphite $\left(\mathrm{P}(\mathrm{OEt})_{3}\right)$ in $[\mathbf{1}] \mathrm{PF}_{6}$ drastically extended the photosensitivity of the complex, covering all visible light and the shorter wavelength region of NIR light (400 - $800 \mathrm{~nm})$. Comparative studies of the photosensitivity with another iron(III) carbonyl complex containing two axial trimethyl phosphine $\left(\mathrm{PMe}_{3}\right)$ ligands, which was chosen as a sterically similar phosphine with stronger $\sigma$-electron donability than $\mathrm{PMe}_{2} \mathrm{Ph}$, suggested that strong $\pi$-backbonding from $\mathrm{Fe} \mathrm{d} \pi$ to $\mathrm{P}-\mathrm{O} \sigma$-antibonding orbitals promoted by the smaller steric bulk of the phosphite ligand induced preferable effects for acquiring extended photosensitivity. 


\section{EXPERIMETAL SECTION}

General procedure. All manipulations were performed under ambient conditions with exception for synthesis of iron(II) complexes $\mathbf{2}-\mathbf{5}$, which were conducted in a glovebox under an atmosphere of oxygen-free dry nitrogen or standard Schlenk techniques under a nitrogen atmosphere. Complexes $\mathbf{2}$ and $\mathbf{3}$ were synthesized according to a literature procedure. The dinuclear iron complex $6\left(\left[\left\{\mathrm{Fe}\left(\mu-\mathrm{PyBPT}-\kappa^{3} N, C, S\right)(\mathrm{CO})_{2}\right\} \mathrm{Fe}(\mathrm{CO})_{3}\right]\right)$ was used as a precursor for 2 and $3^{48-51}$ A $1.0 \mathrm{M}$ toluene solution of trimethylphosphine and triethylphosphite were purchased from Aldrich and Tokyo Chemical Industry Co., Ltd., respectively and were used without further purification. Solvents were purchased from Kanto Chemical Co., Inc. Tris( $p$ tolyl)aminium hexafluorophosphate was prepared according to a literature procedure. ${ }^{53}$ NMR spectra were recorded on a Bruker AVANCE 300 FT-NMR spectrometer at room temperature. IR spectra were recorded on a Shimadzu FTIR-8600PC by a KBr pellet method. Electronic absorption spectra were recorded on a SHIMADZU U-1800, U-3500 or UH4150 spectrophotometer. EPR spectra were measured on a Bruker Biospin Elexsys E500 spectrometer at room temperature. Gas chromatography was performed using a Shimadzu GC-2014 gas chromatograph [GC: Ar carrier, a packed column with ShinCarbon ST $(6.0 \mathrm{~m} \times 3.0 \mathrm{~mm}, 50-80$ mesh) at $363 \mathrm{~K}$ ] equipped with a thermal conductivity detector. Elemental analyses were performed by the Analytical Research Service Center at Osaka City University on J-SCIENCE LAB JM10 or FISONS Instrument EA1108 elemental analyzers.

\section{Synthetic Procedures and Characterization.}

trans-[Fe(PyBPT)(CO)(PMe $\left.)_{2} 2\right]$ (2). The dinuclear iron complex $6(102 \mathrm{mg}, 0.20 \mathrm{mmol})$ was dissolved in toluene $(5 \mathrm{~mL})$ in a Schlenk tube, followed by the addition of trimethylphosphine in toluene $(1.0 \mathrm{M}, 0.80 \mathrm{~mL}, 0.80 \mathrm{mmol})$. The Schlenk tube was heated at $90{ }^{\circ} \mathrm{C}$ for $2 \mathrm{~h}$. The 
resultant red solution was evaporated to dryness. Recrystallization of the residue from THF/nhexane gave needle-like red crystals of $2(96.2 \mathrm{mg}, 97 \%) .{ }^{1} \mathrm{H}$ NMR $\left(300 \mathrm{MHz}, \mathrm{C}_{6} \mathrm{D}_{6}\right) \delta: 0.62$ $\left(18 \mathrm{H}, \mathrm{t},{ }^{2} J_{\mathrm{PH}}={ }^{4} J_{\mathrm{PH}}=3.8 \mathrm{~Hz}, \mathrm{PMe}_{3}\right), 6.05\left(1 \mathrm{H}, \mathrm{ddd},{ }^{3} J_{\mathrm{HH}}=5.8,7.2 \mathrm{~Hz},{ }^{4} J_{\mathrm{HH}}=1.5 \mathrm{~Hz}, 5-\mathrm{py}\right)$, $6.75\left(1 \mathrm{H}, \mathrm{t},{ }^{3} J_{\mathrm{HH}}=7.2 \mathrm{~Hz}, 4-\mathrm{py}\right), 6.94\left(1 \mathrm{H}, \mathrm{ddd},{ }^{3} J_{\mathrm{HH}}=7.0,7.7 \mathrm{~Hz},{ }^{4} J_{\mathrm{HH}}=1.7 \mathrm{~Hz}, 4-\mathrm{BPT}\right), 7.01$ $\left(1 \mathrm{H}, \mathrm{ddd},{ }^{3} J_{\mathrm{HH}}=7.0,7.8 \mathrm{~Hz},{ }^{4} J_{\mathrm{HH}}=1.6 \mathrm{~Hz}, 5-\mathrm{BPT}\right), 7.16\left(1 \mathrm{H}, \mathrm{d},{ }^{3} J_{\mathrm{HH}}=7.2 . \mathrm{Hz}, 3-\mathrm{py}\right), 7.25(1 \mathrm{H}$, $\left.\mathrm{tt},{ }^{3} J_{\mathrm{HH}}=7.6 \mathrm{~Hz}, J_{\mathrm{HP}}=1.5 \mathrm{~Hz}, 5^{\prime}-\mathrm{BPT}\right), 7.49\left(1 \mathrm{H}, \mathrm{dd},{ }^{3} J_{\mathrm{HH}}=7.5 \mathrm{~Hz},{ }^{4} J_{\mathrm{HH}}=1.0 \mathrm{~Hz}, 4^{\prime}-\mathrm{BPT}\right)$, $7.78\left(1 \mathrm{H}, \mathrm{dd},{ }^{3} J_{\mathrm{HH}}=7.9 \mathrm{~Hz},{ }^{4} J_{\mathrm{HH}}=1.6 \mathrm{~Hz}, 6-\mathrm{BPT}\right), 8.04\left(\mathrm{~d},{ }^{3} J_{\mathrm{HH}}=7.8 \mathrm{~Hz}, 1 \mathrm{H}, 66^{\prime}-\mathrm{BPT}\right), 8.10$ $\left(1 \mathrm{H}, \mathrm{dd},{ }^{3} J_{\mathrm{HH}}=7.7 \mathrm{~Hz},{ }^{4} J_{\mathrm{HH}}=1.6 \mathrm{~Hz}, 3-\mathrm{BPT}\right), 8.64\left(1 \mathrm{H}, \mathrm{d},{ }^{3} J_{\mathrm{HH}}=5.8 \mathrm{~Hz} 6-\mathrm{py}\right) .{ }^{13} \mathrm{C}\left\{{ }^{1} \mathrm{H}\right\} \mathrm{NMR}$ $\left(75.5 \mathrm{MHz}, \mathrm{C}_{6} \mathrm{D}_{6}\right) \delta: 14.0\left(\mathrm{t},{ }^{1} J_{\mathrm{CP}}={ }^{3} J_{\mathrm{CP}}=13 \mathrm{~Hz}, \mathrm{PMe}_{3}\right), 117.5(\mathrm{~s}), 120.1(\mathrm{~s}), 121.1\left(\mathrm{t}, J_{\mathrm{CP}}=2.3\right.$ $\mathrm{Hz}), 121.9(\mathrm{~s}), 123.6\left(\mathrm{t}, J_{\mathrm{CP}}=1.9 \mathrm{~Hz}\right), 125.5(\mathrm{~s}), 128.2\left(\mathrm{t}, J_{\mathrm{CP}}=2.6 \mathrm{~Hz}\right), 129.6(\mathrm{~s}), 133.8(\mathrm{~s})$, $134.6(\mathrm{~s}), 141.7(\mathrm{~s}), 144.1(\mathrm{~s}), 144.8\left(\mathrm{t}, J_{\mathrm{CP}}=4.0 \mathrm{~Hz}\right), 147.5\left(\mathrm{t}, J_{\mathrm{CP}}=2.3 \mathrm{~Hz}\right), 153.4(\mathrm{~s}), 168.2(\mathrm{~s})$, $193.4\left(\mathrm{t},{ }^{2} J_{\mathrm{CP}}=28.4 \mathrm{~Hz}, 2^{\prime}-\mathrm{BPT}\right), 215.2\left(\mathrm{t},{ }^{2} J_{\mathrm{CP}}=20.5 \mathrm{~Hz}, \mathrm{CO}\right) .{ }^{31} \mathrm{P}\left\{{ }^{1} \mathrm{H}\right\} \mathrm{NMR}\left(121 \mathrm{MHz}, \mathrm{C}_{6} \mathrm{D}_{6}\right)$ $\delta$ : 15.1 (Figure $\mathrm{S} 11$ - 13). IR $(\mathrm{KBr}) v_{\mathrm{CO}}=1891 \mathrm{~cm}^{-1}$. Calcd for $2\left(\mathrm{C}_{24} \mathrm{H}_{29} \mathrm{FeNOP}_{2} \mathrm{~S}\right): \mathrm{C}, 57.96 ; \mathrm{H}$, 5.88; N, 2.82. Found: C, 57.89; H, 5.91; N, 2.75.

trans- $\left[\mathrm{Fe}(\mathrm{PyBPT})(\mathrm{CO})\left(\mathrm{P}(\mathrm{OEt})_{3}\right)_{2}\right]$ (3). The dinuclear iron complex 6 (1.00 g, $\left.1.9 \mathrm{mmol}\right)$ was dissolved in THF $(8 \mathrm{~mL})$ in a Schlenk tube, and triethylphosphite $(1.40 \mathrm{~mL}, 8.1 \mathrm{mmol})$ was added to the solution. The Schlenk tube was heated at $65^{\circ} \mathrm{C}$ for $4 \mathrm{~h}$. The resultant red solution was evaporated to dryness. The residue was recrystallized from $\mathrm{THF} / n$-hexane at $-30{ }^{\circ} \mathrm{C}$, washed with $n$-hexane, and dried under reduced pressure. Complex 3 was obtained as red needle-like crystals (1.07 g, 81\%). A single crystal suitable for X-ray diffraction analysis was obtained by recrystallization from $\mathrm{THF} / n$-hexane at $-30{ }^{\circ} \mathrm{C} .{ }^{1} \mathrm{H} \mathrm{NMR}\left(300 \mathrm{MHz}, \mathrm{C}_{6} \mathrm{D}_{6}\right): \delta 0.81\left(\mathrm{t},{ }^{3} J_{\mathrm{HH}}=7.0\right.$ $\left.\mathrm{Hz}, 18 \mathrm{H}, \mathrm{P}\left(\mathrm{OCH}_{2} \mathrm{CH}_{3}\right)_{3}\right) 3.76\left(\mathrm{~m}, 12 \mathrm{H}, \mathrm{P}\left(\mathrm{OCH}_{2} \mathrm{CH}_{3}\right)_{3}\right) 6.29\left(\mathrm{ddd},{ }^{3} J_{\mathrm{HH}}=5.8,7.2 \mathrm{~Hz},{ }^{4} J_{\mathrm{HH}}=1.3\right.$ $\mathrm{Hz}, 1 \mathrm{H}, 5-\mathrm{py}), 6.88\left(\mathrm{dd},{ }^{3} J_{\mathrm{HH}}=7.2,7.7 \mathrm{~Hz} 1 \mathrm{H}, 4-\mathrm{py}\right), 6.93\left(\mathrm{ddd},{ }^{3} J_{\mathrm{HH}}=7.0,7.2 \mathrm{~Hz}, J_{\mathrm{HH}}=1.4 \mathrm{~Hz}\right.$, 
1H, 5-BPT), $7.04\left(\mathrm{ddd},{ }^{3} J_{\mathrm{HH}}=7.0,7.6 \mathrm{~Hz},{ }^{4} J_{\mathrm{HH}}=1.5 \mathrm{~Hz}, 1 \mathrm{H}, 4-\mathrm{BPT}\right), 7.28\left(\mathrm{~d},{ }^{3} J_{\mathrm{HH}}=8.1 \mathrm{~Hz}\right.$, $1 \mathrm{H}, 3$-py) $7.31\left(\mathrm{t},{ }^{3} J_{\mathrm{HH}}=7.5 \mathrm{~Hz}, 1 \mathrm{H}, 5^{\prime}-\mathrm{BPT}\right), 7.62\left(\mathrm{dd},{ }^{3} J_{\mathrm{HH}}=7.5 \mathrm{~Hz},{ }^{4} J_{\mathrm{HH}}=0.8 \mathrm{~Hz}, 1 \mathrm{H}, 4^{\prime}-\right.$ BPT), $7.74\left(\mathrm{dd},{ }^{3} J_{\mathrm{HH}}=7.9 \mathrm{~Hz},{ }^{4} J_{\mathrm{HH}}=1.2,1 \mathrm{H}, 6-\mathrm{BPT}\right), 8.01\left(\mathrm{~d},{ }^{3} J_{\mathrm{HH}}=7.5 \mathrm{~Hz}, 1 \mathrm{H}, 6^{\prime}-\mathrm{BPT}\right)$, $8.01\left(\mathrm{dd},{ }^{3} J_{\mathrm{HH}}=7.7 \mathrm{~Hz},{ }^{4} J_{\mathrm{HH}}=1.5 \mathrm{~Hz}, 1 \mathrm{H}, 3-\mathrm{BPT}\right), 8.86\left(\mathrm{~d},{ }^{3} J_{\mathrm{HH}}=5.8 \mathrm{~Hz}, 1 \mathrm{H}, 6-\mathrm{py}\right) .{ }^{13} \mathrm{C}\left\{{ }^{1} \mathrm{H}\right\}$ $\operatorname{NMR}\left(75 \mathrm{MHz}, \mathrm{C}_{6} \mathrm{D}_{6}\right): \delta 16.2\left(\mathrm{t},{ }^{3} J_{\mathrm{CP}}={ }^{5} J_{\mathrm{CP}}=2.5 \mathrm{~Hz}, \mathrm{POCH}_{2} \mathrm{CH}_{3}\right), 61.3\left(\mathrm{t},{ }^{2} J_{\mathrm{CP}}={ }^{4} J_{\mathrm{CP}}=3.5 \mathrm{~Hz}\right.$, $\mathrm{POCH}_{2} \mathrm{CH}_{3}$ ), 117.2 (s), 119.8 (s), 121.0 (t, $2.3 \mathrm{~Hz}$ ), 122.1 (s), 123.7 (s) 125.2 (s), 127.2 (t, 2.6 Hz), 129.4 (s), 134.3 (s), 134.5 (s), 144.1Hz (s), 144.8 (t, 2.6 Hz), 147.5 (t, 4.2 Hz), 148.9 (t, 2.8 $\mathrm{Hz}), 155.3(\mathrm{~s}), 168.7(\mathrm{~s}), 188.2\left(\mathrm{t},{ }^{2} J_{\mathrm{CP}}=35.0 \mathrm{~Hz}, 2^{\prime}-\mathrm{BPT}\right), 214.8\left(\mathrm{t},{ }^{2} J_{\mathrm{CP}}=30.5 \mathrm{~Hz}, \mathrm{CO}\right)$. ${ }^{31} \mathrm{P}\left\{{ }^{1} \mathrm{H}\right\}$ NMR $\left(121 \mathrm{~Hz}, \mathrm{C}_{6} \mathrm{D}_{6}\right): \delta 144.9$ (s) (Figure S14 - 16). IR (KBr) $v_{\mathrm{CO}}=1922 \mathrm{~cm}^{-1}$. Calcd for $3\left(\mathrm{C}_{30} \mathrm{H}_{41} \mathrm{FeNO}_{7} \mathrm{P}_{2} \mathrm{~S}\right)$ : C, 53.18; H, 6.10; N, 2.07. Found: C, 53.20; H, 6.16; N, 2.10. trans- $\left[\mathrm{Fe}(\mathrm{PyBPT})(\mathrm{CO})\left(\mathrm{PMe}_{3}\right)_{2}\right] P F_{6}\left([2] P F_{6}\right)$. Complex $2(90.0 \mathrm{mg}, 0.18 \mathrm{mmol})$ was dissolved in $\mathrm{CH}_{2} \mathrm{Cl}_{2}(2 \mathrm{~mL})$ in a brown vial. The solution was cooled to $0{ }^{\circ} \mathrm{C}$, and then $\mathrm{N}(p \text {-tolyl })_{3} \mathrm{PF}_{6}$ (97.3 mg, $0.23 \mathrm{mmol}$ ) in $\mathrm{CH}_{2} \mathrm{Cl}_{2}(1 \mathrm{~mL})$ was added. After stirring for $20 \mathrm{~min}, 0.5 \mathrm{~mL}$ of diethyl ether was added to the reaction mixture, followed by additional stirring for $5 \mathrm{~min}$. The resultant solution was evaporated to dryness. The residue was suspended in toluene $(2 \mathrm{~mL})$ to collect precipitates by filtration, which was washed with toluene, and was dried under reduced pressure. [2] $\mathrm{PF}_{6}$ was obtained as reddish-purple powder. Yield: $99.3 \mathrm{mg}, 85 \%$. A single crystal suitable for X-ray diffraction analysis was obtained by recrystallization from $\mathrm{CH}_{2} \mathrm{Cl}_{2}$ /toluene at $4{ }^{\circ} \mathrm{C} . v_{\mathrm{CO}}=$ $1998 \mathrm{~cm}^{-1}$ Calcd for $[2] \mathrm{PF}_{6} \cdot 0.33 \mathrm{CH}_{2} \mathrm{Cl}_{2}\left(\mathrm{C}_{24} \mathrm{H}_{29} \mathrm{~F}_{6} \mathrm{FeNOP}_{3} \mathrm{~S} \cdot 0.33 \mathrm{CH}_{2} \mathrm{Cl}_{2}\right): \mathrm{C}, 43.59 ; \mathrm{H}, 4.46 ; \mathrm{N}$, 2.09. Found: C, 43.37; H, 4.60; N, 1.97.

trans- $\left[\mathrm{Fe}(\mathrm{PyBPT})(\mathrm{CO})\left(\mathrm{P}(\mathrm{OEt})_{3}\right)_{2}\right] P F_{6} \quad\left([3] P F_{6}\right)$. Complex $3(135 \mathrm{mg}, 0.20 \mu \mathrm{mol})$ was dissolved in $\mathrm{CH}_{2} \mathrm{Cl}_{2}(2 \mathrm{~mL})$ in a brown vial. To the cooled solution at $0{ }^{\circ} \mathrm{C}$ was added $\mathrm{N}(p$ tolyl $)_{3} \mathrm{PF}_{6}(94.0 \mathrm{mg}, 0.22 \mu \mathrm{mol})$ dissolved in $\mathrm{CH}_{2} \mathrm{Cl}_{2}(3 \mathrm{~mL})$. After $10 \mathrm{~min}$ stirring, the solution 
was added $0.5 \mathrm{~mL}$ diethyl ether, followed by stirring for $10 \mathrm{~min}$. The resultant solution was evaporated to dryness. The residue dissolved in $\mathrm{CH}_{2} \mathrm{Cl}_{2}(1 \mathrm{~mL})$ was reprecipitated in toluene (20 $\mathrm{mL}$ ), which was collected by filtration, washed with toluene, and dried under reduced pressure. Complex [3] $\mathrm{PF}_{6}$ was obtained as dark blue powder. Yield: $137 \mathrm{mg}, 84 \%$. A single crystal suitable for X-ray diffraction analysis was obtained by recrystallization from $\mathrm{CH}_{2} \mathrm{Cl}_{2}$ /toluene at 4 ${ }^{\circ} \mathrm{C} . v_{\mathrm{CO}}=2011 \mathrm{~cm}^{-1}$ Calcd for $[3] \mathrm{PF}_{6} \cdot \mathrm{H}_{2} \mathrm{O}\left(\mathrm{C}_{30} \mathrm{H}_{41} \mathrm{~F}_{6} \mathrm{FeNO}_{7} \mathrm{P}_{3} \mathrm{~S} \cdot \mathrm{H}_{2} \mathrm{O}\right): \mathrm{C}, 42.87 ; \mathrm{H}, 5.16 ; \mathrm{N}$, 1.67. Found: C, 43.81; H, 5.02; N, 1.70 .

$\left[\mathrm{Fe}\left(\mathrm{PyBPT}-\kappa^{3} \mathrm{~N}, \mathrm{C}, \mathrm{S}\right)(\mathrm{CO}) \mathrm{P}(\mathrm{OEt})_{3}\right]_{2}$ (4). The dinuclear iron complex 6 (26 $\left.\mathrm{mg}, 0.05 \mathrm{mmol}\right)$ was dissolved in toluene $(5 \mathrm{~mL})$ in a Schlenk tube, and triethylphosphite $(55 \mu \mathrm{L}, 0.3 \mathrm{mmol})$ was added to the solution. The Schlenk tube was heated at $100{ }^{\circ} \mathrm{C}$ overnight. The red suspension evaporated to dryness, and the residue was suspended in $n$-hexane. The residue was washed with $n$-hexane and dried under reduced pressure. Complex 4 was obtained as a reddish orange solid (5.9 mg, 22\%). Single crystals suitable for X-ray diffraction analysis were obtained by standing a $\mathrm{C}_{6} \mathrm{D}_{6}$ solution of 3 at room temperature for a month. ${ }^{1} \mathrm{H}$ NMR $\left(300 \mathrm{MHz}, \mathrm{C}_{6} \mathrm{D}_{6}\right): \delta 0.49\left(\mathrm{t},{ }^{3} J_{\mathrm{HH}}=\right.$ $\left.7.0 \mathrm{~Hz}, 9 \mathrm{H}, \mathrm{P}\left(\mathrm{OCH}_{2} \mathrm{CH}_{3}\right)_{3}\right), 3.17\left(\mathrm{dm}, 6 \mathrm{H}, \mathrm{P}\left(\mathrm{OCH}_{2} \mathrm{CH}_{3}\right)_{3}\right), 5.91\left(\mathrm{dd},{ }^{3} J_{\mathrm{HH}}=7.7 \mathrm{~Hz},{ }^{4} J_{\mathrm{HH}}=1.4\right.$ $\mathrm{Hz}, 1 \mathrm{H}), 6.06\left(\mathrm{ddd},{ }^{3} J_{\mathrm{HH}}=5.8,7.2 \mathrm{~Hz},{ }^{4} J_{\mathrm{HH}}=1.4 \mathrm{~Hz}, 1 \mathrm{H}\right), 6.66\left(\mathrm{dt},{ }^{3} J_{\mathrm{HH}}=7.4 \mathrm{~Hz},{ }^{4} J_{\mathrm{HH}}=1.3 \mathrm{~Hz}\right.$, $1 \mathrm{H}), 6.89\left(\mathrm{t},{ }^{3} J_{\mathrm{HH}}=7.4 \mathrm{~Hz}, 1 \mathrm{H}\right), 7.24\left(\mathrm{t},{ }^{3} J_{\mathrm{HH}}=7.4 \mathrm{~Hz}, 1 \mathrm{H}\right), 7.53\left(\mathrm{~d},{ }^{3} J_{\mathrm{HH}}=8.0 \mathrm{~Hz}, 1 \mathrm{H}\right), 7.72(\mathrm{t}$, $\left.{ }^{3} J_{\mathrm{HH}}=7.6 \mathrm{~Hz}, 2 \mathrm{H}\right), 8.07\left(\mathrm{~d},{ }^{3} J_{\mathrm{HH}}=7.7 \mathrm{~Hz}, 1 \mathrm{H}\right), 8.20\left(\mathrm{~d},{ }^{3} J_{\mathrm{HH}}=5.7 \mathrm{~Hz}, 1 \mathrm{H}\right), 8.54\left(\mathrm{~d},{ }^{3} J_{\mathrm{HH}}=7.5\right.$ $\mathrm{Hz}, 1 \mathrm{H}, 6-\mathrm{py}) .{ }^{31} \mathrm{P}\left\{{ }^{1} \mathrm{H}\right\}$ NMR $\left(121 \mathrm{~Hz}, \mathrm{C}_{6} \mathrm{D}_{6}\right): \delta 165.7$ (s). IR(KBr): $v_{\mathrm{CO}} / \mathrm{cm}^{-1} 1930$. Calcd for $4 \cdot \mathrm{H}_{2} \mathrm{O}\left(\mathrm{C}_{48} \mathrm{H}_{52} \mathrm{Fe}_{2} \mathrm{~N}_{2} \mathrm{O}_{8} \mathrm{P}_{2} \mathrm{~S}_{2} \cdot \mathrm{H}_{2} \mathrm{O}\right): \mathrm{C}, 55.40 ; \mathrm{H}, 5.23 ; \mathrm{N}, 2.69$. Found: C, 55.45; H, 5.15; N, 2.64. trans- $\left[\mathrm{Fe}(\mathrm{PyBPT})\left(\mathrm{CN}^{t} \mathrm{Bu}\right)\left(\mathrm{PMe}_{2} \mathrm{Ph}\right)_{2}\right] \quad$ (5). Complex $\quad\left[\begin{array}{l}5\end{array}\right] \mathrm{PF}_{6} \quad\left(\begin{array}{lllll}8.0 & \mathrm{mg}, & 9.7 & \mu \mathrm{mol}\end{array}\right)$ and cobaltocene $(2.4 \mathrm{mg}, 13 \mu \mathrm{mol})$ were dissolved in $3 \mathrm{~mL}$ THF. The solution was stirred at room temperature for $5 \mathrm{~min}$. The reaction mixture was evaporated to dryness. The residue was added 
toluene, and the suspension was passed through Celite pad. The filtrate was evaporated to dryness. To the oily residue, $n$-pentane was added and evaporated to dryness. Complex $\mathbf{5}$ was obtained as red brown powder $(5.0 \mathrm{mg}, 76 \%)$. Single crystals suitable for X-ray diffraction analysis were obtained by recrystallization from $n$-pentane at $-30{ }^{\circ} \mathrm{C} .{ }^{1} \mathrm{H}$ and ${ }^{31} \mathrm{P}\left\{{ }^{1} \mathrm{H}\right\}$ NMR data are consistent with the previous report. ${ }^{52} \mathrm{C}\left\{{ }^{1} \mathrm{H}\right\} \mathrm{NMR}\left(75 \mathrm{MHz}, \mathrm{C}_{6} \mathrm{D}_{6}\right): \delta 11.9\left(\mathrm{t},{ }^{1} J_{\mathrm{CP}}={ }^{3} J_{\mathrm{CP}}=\right.$ $\left.13 \mathrm{~Hz}, \mathrm{PMe}_{2} \mathrm{Ph}\right), 13.6\left(\mathrm{t},{ }^{1} J_{\mathrm{CP}}={ }^{3} J_{\mathrm{CP}}=13 \mathrm{~Hz}, \mathrm{PMe}_{2} \mathrm{Ph}\right), 31.6\left(\mathrm{~s}, \mathrm{CNCMe}_{3}\right), 56.1\left(\mathrm{~s}, \mathrm{CNCMe}_{3}\right)$, $116.6(\mathrm{~s}), 119.0(\mathrm{~s}), 120.4\left(\mathrm{t}, J_{\mathrm{CP}}=1.9 \mathrm{~Hz}\right), 121.3(\mathrm{~s}), 122.3\left(\mathrm{t}, J_{\mathrm{CP}}=1.8 \mathrm{~Hz}\right), 124.9(\mathrm{~s}), 127.1$ $(\mathrm{s}), 127.3\left(\mathrm{t}, J_{\mathrm{CP}}=3.5 \mathrm{~Hz}\right), 127.9(\mathrm{~s}), 128.2(\mathrm{~s}), 129.4(\mathrm{t}, \mathrm{JCP}=3.8 \mathrm{~Hz}), 129.8 \mathrm{~Hz}(\mathrm{~s}), 130.9(\mathrm{~s})$, $134.8(\mathrm{~s}), 140.4\left(\mathrm{t}, J_{\mathrm{CP}}=11.5 \mathrm{~Hz}\right), 142.6(\mathrm{~s}), 146.2(\mathrm{~s}), 146.7\left(\mathrm{t}, J_{\mathrm{CP}}=3.5 \mathrm{~Hz}\right), 148.8\left(\mathrm{t}, J_{\mathrm{CP}}=1.5\right.$ $\mathrm{Hz}), 152.9(\mathrm{~s}), 168.3(\mathrm{~s}), 197.7\left(\mathrm{t},{ }^{2} J_{\mathrm{CP}}=26.6 \mathrm{~Hz}\right) . \mathrm{IR}(\mathrm{KBr}): v_{\mathrm{CN}} / \mathrm{cm}^{-1}$ 2032. Calcd for $\mathrm{C}_{38} \mathrm{H}_{42} \mathrm{FeN}_{2} \mathrm{P}_{2} \mathrm{~S}: \mathrm{C}, 67.45 ; \mathrm{H}, 6.26 ; \mathrm{N}, 4.14$. Found: C, 67.18; H, 6.28; N, 4.08.

Quantification of the released CO from complexes. $15 \mathrm{mg}$ of complex [3] $\mathrm{PF}_{6} \mathrm{Was}$ dissolved in $1 \mathrm{~mL} \mathrm{CH}_{2} \mathrm{Cl}_{2}$ in a $12 \mathrm{~mL}$ vial, which was tightly capped with a rubber septum. After irradiating the solution by white LED for $3 \mathrm{~h}, 500 \mu \mathrm{L}$ of the gas in the headspace was taken up by a gas tight syringe for subsequent analysis by gas chromatography. Standard samples to obtain a CO calibration curve was prepared by injecting specific amount of pure CO gas in place of the complex to the same experimental setting mentioned above. The CO release efficiency was determined by dividing the detected amount of $\mathrm{CO}$ by the stoichiometric amount of $\mathrm{CO}$ released from the added complex. The mean of the $\mathrm{CO}$ efficiency of three independent experiments was 1.02 , and the standard deviation was 0.04 .

Photochemistry. Quantitative photoreactions were performed under dim red light to minimize the effect of photoreactions induced by ambient light. The quantum yields for CO-release reaction of $[1] \mathrm{PF}_{6}-[3] \mathrm{PF}_{6}$ were determined by irradiation of monochromic light using a built-in 
xenon lamp of a fluorescence spectrophotometer (F-7000, Hitachi) with $20 \mathrm{~nm}$ bandwidths through a UV or yellow filter to cut off the light diffracted at higher order of the incident light. Dichloromethane solutions of $[1] \mathrm{PF}_{6}-[3] \mathrm{PF}_{6}$ in the presence of excess amount of $1,10-$ phenanthroline were used for the quantum-yield determination. Electronic absorption spectroscopy was used to quantitate the increase of $\mathrm{Fe}^{2+}$ ion concentration, which is formed from CO-dissociated complexes. The molar absorption coefficient of tris(1,10-phenanthroline)iron(II) bishexafluorophosphate $\left(\left[\mathrm{Fe}(\text { phen })_{3}\right]\left(\mathrm{PF}_{6}\right)_{2}\right)^{54}$ in $\mathrm{CH}_{2} \mathrm{Cl}_{2}$ at $509 \mathrm{~nm}$ was determined to $1.1 \times 10^{4}$ $\mathrm{mol}^{-1} \mathrm{dm}^{3} \mathrm{~cm}^{-1}$, which was used to determine the $\mathrm{Fe}^{2+}$ concentration produced in the photoreaction. Two samples were prepared to subtract the influence of thermal decomposition and photoreaction by ambient light. One sample was irradiated on the spectrophotometer, and the other was standing in the same sample chamber under light shield. At six different irradiation periods, the absorption spectra of both the irradiated and control samples were measured to plot the produced $\left[\mathrm{Fe}(\text { phen })_{3}\right]^{2+}$ as a function of photon numbers. The quantum yield was calculated from the average of three independent experiments. Potassium tetrathiocyanatodiamminechromate(III) monohydrate (potassium Reinecke's salt) ${ }^{55,56}$ was used as a chemical actinometer to determine the intensity of the incident light at each wavelength prior to sample measurements.

X-ray Crystal Structure Determination. Diffraction data of 2 - 5, [2]PF 6 and $[3] \mathrm{PF}_{6}$ were collected on a Rigaku AFC11/Saturn 724+ CCD diffractometer. The data were processed and corrected for Lorentz and polarization effects using the CrystalClear software package. ${ }^{57}$ The minimum $\theta$ value was set to $3.0^{\circ}$ to avoid problems related to strong saturated peaks. The analyses were carried out using the WinGX software. ${ }^{58}$ Absorption corrections were applied using the Multi Scan method. The structures were solved using direct methods (SIR97 ${ }^{59}$ ) and 
refined by full-matrix least-squares on $F_{2}$ using SHELXL-2013. ${ }^{60}$ Crystallographic data are summarized in Tables S4 and 5. Non-hydrogen atoms were refined anisotropically. Hydrogen atoms of the $\mathrm{P}(\mathrm{OEt})_{3}$ ligands in 3 and $[3] \mathrm{PF}_{6}$, the disordered ethyl group of $\mathrm{P}(\mathrm{OEt})_{3}$ in $\mathbf{4}$, and the $\mathrm{PMe}_{3}$ ligands in $[2] \mathrm{PF}_{6}$ were placed in calculated positions with $\mathrm{C}-\mathrm{H}($ methyl $)=0.98 \AA$ and $\mathrm{C}-$ $\mathrm{H}($ methylene $)=0.99 \AA$ and refined using a riding model with $U_{\mathrm{iso}}(\mathrm{H})=1.5 U_{\mathrm{eq}}(\mathrm{C})$ and $1.2 U_{\mathrm{eq}}(\mathrm{C})$, respectively. Hydrogen atoms of a hexane molecule found for $\mathbf{3}$ were also treated using the riding model. Other $\mathrm{H}$ atoms were found in a difference Fourier map and refined isotropically.

Computational Details. Structures of complexes 2, 3, $[2]^{+}$, and $[3]^{+}$were optimized by DFT calculations using the Gaussian 03 program package. ${ }^{61}$ The rB3LYP (for 2 and $\mathbf{3}$ ) or uB3LYP (for $[2]^{+}$and $[3]^{+}$) density functional method and the $6-311+\mathrm{G}(\mathrm{d}, \mathrm{p})$ basis set were used for the calculations. The initial models were obtained from the crystal structures. Optimized structures and selected molecular orbitals of $\mathbf{2}, \mathbf{3},[\mathbf{2}]^{+}$, and $[\mathbf{3}]^{+}$are shown in Figure S6 and their molecular coordinates and selected bond distances and angles are listed in Tables S6, 8, 10, 11, 13 and 15, respectively. Harmonic vibrational frequencies were calculated for the optimized geometries using the 6-311G(d,p) level. Time-dependent DFT calculations were performed using the optimized structures at the rB3LYP/6-311+G(d,p) or uB3LYP/6-311+G(d,p) level. Calculated electronic transitions for $\mathbf{2}, \mathbf{3},[2]^{+}$, and $[3]^{+}$are given in Tables S7, S9, S12 and S14, respectively.

\section{RESULTS AND DISCUSSION}

Synthesis and properties of $N, C, S$-pincer iron(II) carbonyl complexes. Mononuclear iron(II) complexes of an N,C,S-pincer ligand, with either $\mathrm{PMe}_{3}$ or $\mathrm{P}(\mathrm{OEt})_{3}$ ligand trans$\left[\mathrm{Fe}(\mathrm{PyBPT})(\mathrm{CO})\left(\mathrm{PR}_{3}\right)_{2}\right](\mathbf{2}$ for $\mathrm{R}=\mathrm{Me}, \mathbf{3}$ for $\mathrm{R}=\mathrm{OEt})$, were synthesized by a procedure similar to that of $\mathbf{1}$, which was obtained via heterolytic $\mathrm{Fe}-\mathrm{Fe}$ bond cleavage of the dinuclear iron 
complex $6^{62}$ according to a previous report (Scheme 1). ${ }^{51}$ Complex 6 reacted with four equivalents of $\mathrm{PMe}_{3}$ or $\mathrm{P}(\mathrm{OEt})_{3}$ in THF at $65{ }^{\circ} \mathrm{C}$ to provide 2 or $\mathbf{3}$, respectively, as reddish solution. Dark red crystals of $\mathbf{2}$ or red crystals of $\mathbf{3}$ were obtained by recrystallization of the resultant solution from
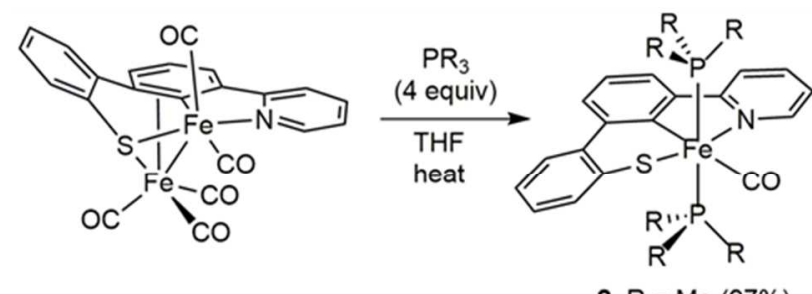

2, $R=M e(97 \%)$

$3, \mathrm{R}=\mathrm{OEt}(81 \%)$

Scheme 1. Synthesis of iron(II) carbonyl complexes $\mathbf{2}$ and $\mathbf{3}$.
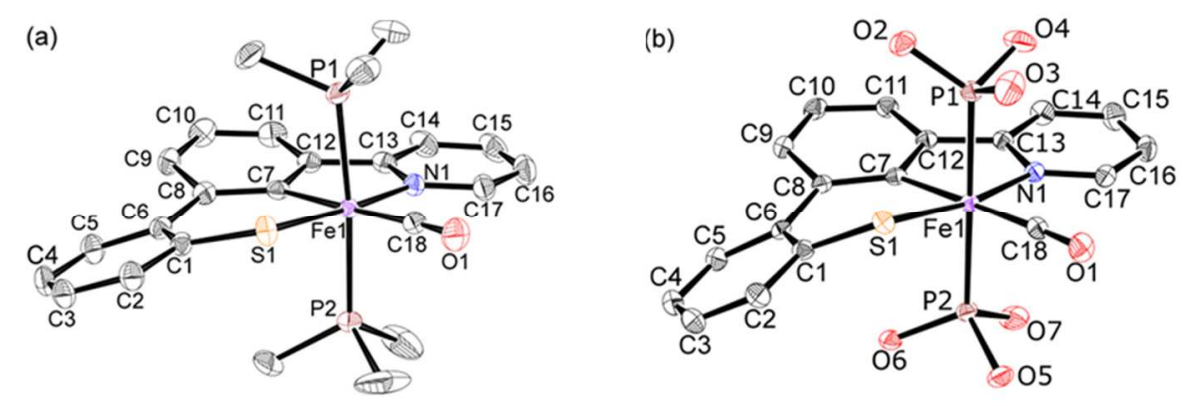

Figure 2. ORTEP drawings of (a) 2 and (b) 3 with thermal ellipsoids at 50\% probability level. Hydrogen atoms, crystal solvents, and ethyl groups of $\mathrm{P}(\mathrm{OEt})_{3}$ in $\mathbf{3}$ are omitted for clarity.

THF/n-hexane, as reported for $\mathbf{1} .^{48,51}$ The crystal structures of $\mathbf{2}$ and $\mathbf{3}$ are depicted in Figure 2. Selected bond distances and angles of $\mathbf{2}$ and $\mathbf{3}$ are listed in Table 1. Corresponding data for $\mathbf{1}$ are reproduced in the table for comparison. Virtually identical coordination bond distances were found in the equatorial plane ligands of $\mathbf{1}$ - 3. Fe-P distances in each complex were consistent with the non-planar configuration of the equatorial plane particularly composed of C1 - 8 and S1. The ${ }^{1} \mathrm{H}$ and ${ }^{31} \mathrm{P}\{1 \mathrm{H}\}$ NMR spectra of $\mathbf{1} \mathbf{- 3}$, however, indicated that the two phosphorus ligands were equally bound to $\mathrm{Fe}$ in the trans position. The variance in the crystal and NMR data 
supposes the quick flip-flop motion of the equatorial ligand in solution. The mean Fe-P distance of 3 was ca. $2.206 \AA$, which was comparable with those of other reported iron(II) phosphite complexes and was shorter than those of $\mathbf{1}$ and $\mathbf{2}$ by 0.05 and $0.04 \AA$, respectively. The shorter bond distance observed for $\mathrm{P}(\mathrm{OEt})_{3}$ coordination was ascribed to the lower steric bulk relative to the phosphine ligands.

Table 1. Selected bond lengths and angles of 1 - 3.

\begin{tabular}{llll}
\hline Complex & $\mathbf{1}^{[\mathrm{a}]}$ & $\mathbf{2}$ & $\mathbf{3}$ \\
\hline $\mathrm{Fe} 1-\mathrm{S} 1 / \AA$ & $2.2884(5)$ & $2.2777(7)$ & $2.2915(10)$ \\
$\mathrm{Fe} 1-\mathrm{C} 7 / \AA$ & $1.9872(17)$ & $1.997(2)$ & $2.005(3)$ \\
$\mathrm{Fe} 1-\mathrm{N} 1 / \AA$ & $1.9876(15)$ & $1.9799(19)$ & $1.989(3)$ \\
$\mathrm{Fe} 1-\mathrm{C} 18 / \AA$ & $1.7591(19)$ & $1.761(2)$ & $1.773(4)$ \\
$\mathrm{Fe} 1-\mathrm{P} 1 / \AA$ & $2.2665(6)$ & $2.2511(8)$ & $2.2193(10)$ \\
$\mathrm{Fe} 1-\mathrm{P} 2 / \AA$ & $2.2341(6)$ & $2.2340(8)$ & $2.1924(10)$ \\
$\mathrm{C} 18-\mathrm{O} 1 / \AA$ & $1.164(2)$ & $1.161(3)$ & $1.156(4)$ \\
$\mathrm{Fe} 1-\mathrm{C} 18-\mathrm{O} 1{ }^{\circ}$ & $178.3(2)$ & $176.2(2)$ & $178.2(3)$ \\
$\mathrm{N} 1-\mathrm{Fe} 1-\mathrm{S} 1{ }^{\circ}$ & $173.82(5)$ & $175.97(6)$ & $171.16(8)$ \\
$\mathrm{C} 7-\mathrm{Fe} 1-\mathrm{C} 18 /{ }^{\circ}$ & $177.96(8)$ & $178.46(10)$ & $178.05(15)$ \\
$\mathrm{P} 1-\mathrm{Fe} 1-\mathrm{P} 2{ }^{\circ}$ & $174.58(2)$ & $174.68(3)$ & $179.27(4)$ \\
$\begin{array}{l}\text { Interplanar } \\
\text { angle }^{[\mathrm{b}]}\end{array}$ & $35.72(9)$ & $22.46(5)$ & $27.08(10)$ \\
$\begin{array}{l}\text { Interplanar } \\
\text { angle }^{[\mathrm{c}]}\end{array}$ & $16.22(13)$ & $7.83(4)$ & $6.26(15)$ \\
\hline
\end{tabular}

[a] Referred from ref. 46. [b] Interplanar angles were calculated as the dihedral angle between the leastsquares planes of $\mathrm{C}(1)-\mathrm{C}(6)$ and $\mathrm{C}(7)-\mathrm{C}(12)$. [c] Interplanar angles were calculated as the dihedral angle between the least-squares planes of $\mathrm{C}(7)-\mathrm{C}(12)$ and C(13)-C(17), N(1). 
The Tolman corn angle - a common measure for the bulkiness of phosphorous ligandsdetermined for the $\mathrm{P}(\mathrm{OEt})_{3}$ ligand $\left(109^{\circ}\right)$, was significantly smaller than those for the phosphine ligands $\left(122^{\circ}\right.$ for $\mathrm{PMe}_{2} \mathrm{Ph}$ and $118^{\circ}$ for $\left.\mathrm{PMe}_{3}\right){ }^{63}$ Complex 3 had the propensity of thermally dissociating one of the phosphite ligands and getting converted to the dinuclear complex 4 (Scheme 2). ${ }^{64}$ This reaction lowered the yield of the monomer complex 3 in the present synthetic

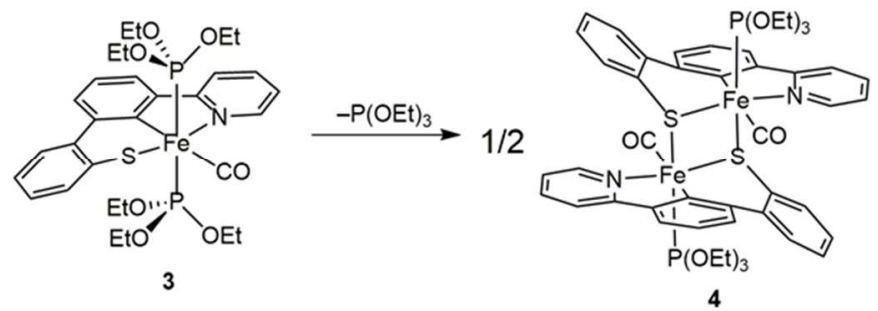

Scheme 2. Formation of diiron(II,II) complex 4 from iron(II) complex 3.

process. Single-crystal X-ray diffraction analysis revealed that $\mathbf{4}$ was a thiolate-bridged dinuclear iron(II,II) complex consisting of two $\mathrm{Fe}(\mathrm{PyBPT})(\mathrm{CO})\left(\mathrm{P}(\mathrm{OEt})_{3}\right)$ units related by a crystallographic inversion center (Figure S1, Table S1). The Fe-P1 distance of 4 (2.1629(7) Å) was $0.03 \AA$ shorterthan the Fe-P2 distance of 3 because of the replacement of one of the $\pi$ accepting phosphite ligands by a $\pi$-donating thiolate at the trans position. In contrast, the $\mathrm{Fe}-\mathrm{CO}$ bond was not affected by dimerization. Similar Fe-CO distances and $\mathrm{CO}$ stretching frequencies of carbonyl ligands were observed in $\mathbf{3}$ and $\mathbf{4}$. Complex $\mathbf{4}$ is another potential candidate for ironbased CORM with phosphite ligands. Poor solubility of the complex in both organic and aqueous solvents, however, prevented further study to examine $\mathrm{CO}$ release from this complex upon photo-irradiation. The electronic effect of the phosphite ligand on $\mathbf{3}$ was estimated from the $\mathrm{C}-\mathrm{O}$ stretching frequency of the carbonyl ligand. The IR spectrum of $\mathbf{3}$ showed a $\mathrm{C}-\mathrm{O}$ stretching band at $1922 \mathrm{~cm}^{-1}$, which was much higher than those of $\mathbf{1}\left(1890 \mathrm{~cm}^{-1}\right)$ and $\mathbf{2}\left(1891 \mathrm{~cm}^{-1}\right) .{ }^{51}$ This trend in $\mathrm{CO}$ frequency $(\mathbf{3}>\mathbf{2} \approx \mathbf{1})$ indicated weaker electron donability and/or stronger electron 
acceptability of the phosphite ligand than the phosphine ligands. This was coincident with the general order of Tolman's electronic parameter for phosphorus ligands. ${ }^{62,63}$ The absorption spectra of $\mathbf{1}-\mathbf{3}$ in $\mathrm{CH}_{2} \mathrm{Cl}_{2}$ are shown in Figure 3. In all spectra, d-d transition bands were observed around $500 \mathrm{~nm}\left(550 \mathrm{~nm}\right.$ for $\mathbf{1},{ }^{51} 550 \mathrm{~nm}$ for $\mathbf{2}$, and $510 \mathrm{~nm}$ for $\left.\mathbf{3}\right)$ as shoulders, while charge-transfer bands, including the metal-to-ligand and intra-ligand charge-transfer showed intense absorption bands at around $400 \mathrm{~nm}(383$ and $408 \mathrm{~nm}$ for $\mathbf{1}, 417 \mathrm{~nm}$ for 2 , and $382 \mathrm{~nm}$ for 3). ${ }^{51}$ The overall blue shift of the bands in 3 supported the stronger $\pi$-acceptability of the phosphite ligand stabilizing the filled $\mathrm{d} \pi(\mathrm{Fe})$ orbitals.

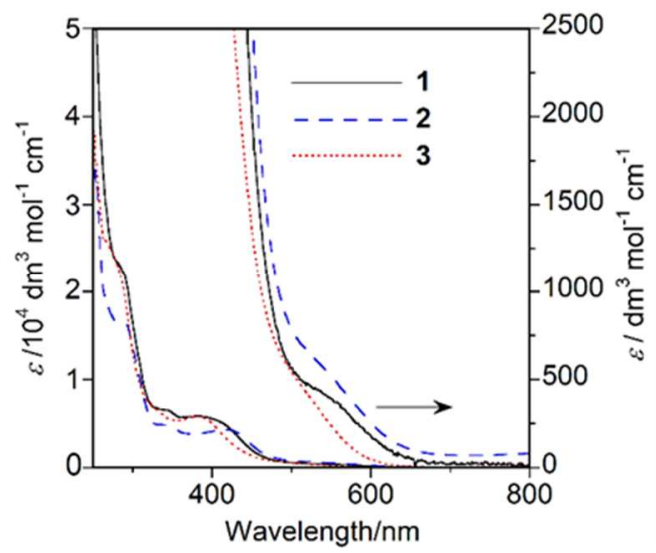

Figure 3. Electronic absorption spectra of 1 (solid black line), $\mathbf{2}$ (blue dashed line), and $\mathbf{3}$ (red dotted line) in $\mathrm{CH}_{2} \mathrm{Cl}_{2}$.

\section{Preparation and properties of $N, C, S$-pincer iron(III) carbonyl complexes. One-electron-} oxidation products of $\mathbf{2}$ and $\mathbf{3}\left([2] \mathrm{PF}_{6}\right.$ and $\left.[3] \mathrm{PF}_{6}\right)$ were obtained as reddish purple and dark blue solids, respectively by reaction with $\mathrm{N}(p$-tolyl $){ }_{3} \mathrm{PF}_{6}$ in the dark (Scheme 3$)$. The crystal structures

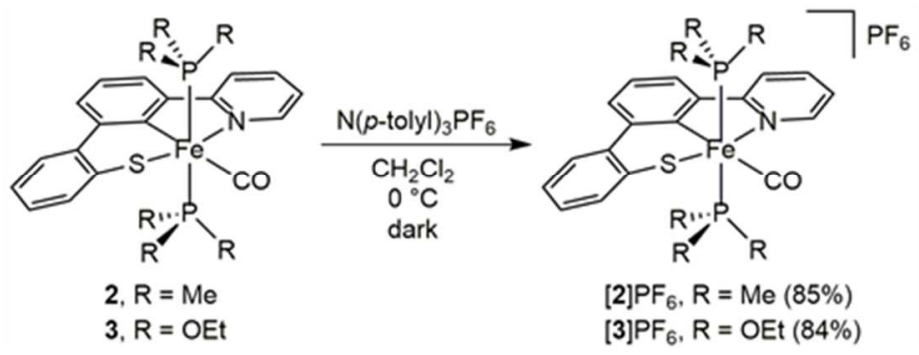


Scheme 3. Preparation of iron(III) carbonyl complexes [2] $\mathrm{PF}_{6}$ and $[3] \mathrm{PF}_{6}$.

of $[2] \mathrm{PF}_{6}$ and $[3] \mathrm{PF}_{6}$ are shown in Figure 4, and selected bond lengths and angles are listed in Table 2 together with sets of $[1] \mathrm{PF}_{6}$ for comparison. Although the geometries of the iron(II) complexes were conserved after the oxidation reaction, some variation was found in certain bond lengths and angles. Significant reductions in Fe-S bond lengths were observed in both [2]PF 6 and
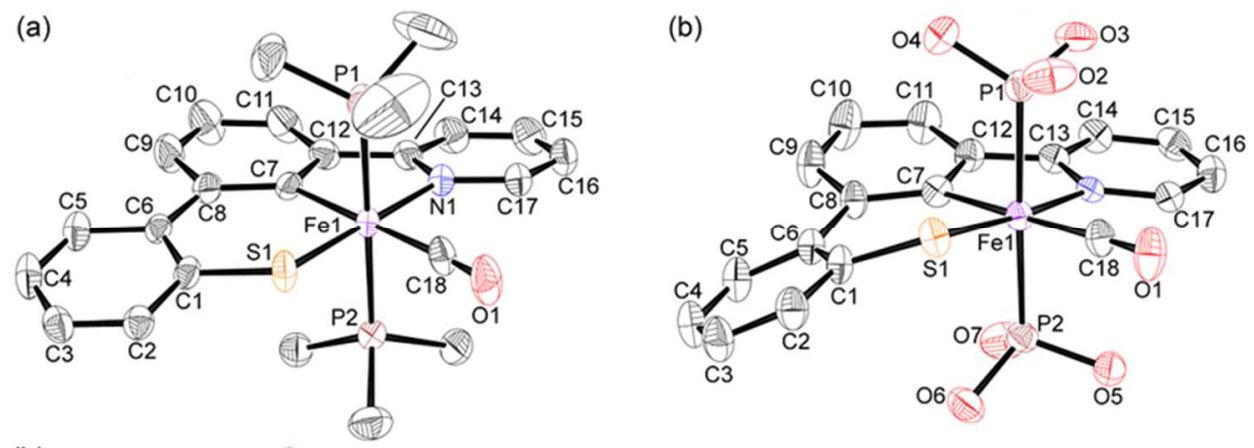

Figure 4. ORTEP drawings of the cations of (a) $[2] \mathrm{PF}_{6}$ and (b) $[3] \mathrm{PF}_{6}$ with thermal ellipsoids at $50 \%$ probability level. Hydrogen atoms of the cations and ethyl groups of $\mathrm{P}(\mathrm{OEt})_{3}$ in $[3] \mathrm{PF}_{6}$ are omitted for clarity.

Table 2. Selected bond lengths and angles of $[1] \mathrm{PF}_{6}-[3] \mathrm{PF}_{6}$.

\begin{tabular}{llll}
\hline Complex & {$[1] \mathrm{PF}_{6}{ }^{[\mathrm{a}]}$} & {$[2] \mathrm{PF}_{6}{ }^{[\mathrm{b}]}$} & {$[3] \mathrm{PF}_{6}$} \\
\hline $\mathrm{Fe} 1-\mathrm{S} 1 / \AA$ & $2.1532(8)$ & $2.1364(13), 2.1439(13)$ & $2.1436(11)$ \\
$\mathrm{Fe} 1-\mathrm{C} 7 / \AA$ & $1.988(3)$ & $1.989(4), 1.991(4)$ & $1.976(3)$ \\
$\mathrm{Fe} 1-\mathrm{N} 1 / \AA$ & $2.003(2)$ & $1.993(3), 1.997(3)$ & $1.997(3)$ \\
$\mathrm{Fe} 1-\mathrm{C} 18 / \AA$ & $1.817(3)$ & $1.812(4), 1.818(4)$ & $1.814(4)$ \\
$\mathrm{Fe} 1-\mathrm{P} 1 / \AA$ & $2.3123(8)$ & $2.2894(14), 2.3018(13)$ & $2.2513(12)$ \\
$\mathrm{Fe} 1-\mathrm{P} 2 / \AA$ & $2.2937(8)$ & $2.2927(13), 2.2963(12)$ & $2.2375(12)$ \\
$\mathrm{C} 18-\mathrm{O} 1 / \AA$ & $1.141(4)$ & $1.148(5), 1.142(5)$ & $1.140(4)$ \\
$\mathrm{Fe} 1-\mathrm{C} 18-\mathrm{O} 1 /{ }^{\circ}$ & $175.5(3)$ & $175.3(4), 177.1(4)$ & $178.0(3)$
\end{tabular}




$\begin{array}{llll}\text { N1-Fe1-S1/ } & 175.66(7) & 177.84(10), 177.15(10) & 175.59(8) \\ \text { C7-Fe1-C18/ } & 175.68(12) & 179.35(18), 178.52(17) & 177.56(14) \\ \text { P1-Fe1-P2/ } & 174.54(3) & 175.80(5), 176.08(5) & 172.73(4) \\ \begin{array}{l}\text { interplanar } \\ \text { angle }{ }^{[\mathrm{c}] / 0}\end{array} & 27.65(10) & 14.5(3), 19.3(2) & 26.23(11) \\ \begin{array}{l}\text { interplanar } \\ \text { angle }[\mathrm{d}] / \mathrm{o}\end{array} & 12.05(10) & 8.3(3), 13.5(3) & 9.72(7) \\ \end{array}$

[a] Referred from ref. 50. [b] There are two independent molecules in the asymmetric unit, and one of the molecules is shown in Figure 4a. [c] Interplanar angles were calculated as the dihedral angle between the leastsquares planes of $\mathrm{C}(1)-\mathrm{C}(6)$ and $\mathrm{C}(7)-\mathrm{C}(12)$. [d] Interplanar angles were calculated as the dihedral angle between the least-squares planes of $\mathrm{C}(7)-\mathrm{C}(12)$ and $\mathrm{C}(13)-\mathrm{C}(17), \mathrm{N}(1)$.

$[3] \mathrm{PF}_{6}$, which were due to removal of an electron from $\mathrm{Fe}-\mathrm{S} \pi$-antibonding orbitals participating in the HOMO of $\mathbf{2}$ and $\mathbf{3}^{52}$ In addition, the $\mathrm{Fe}-\mathrm{CO}$ and $\mathrm{Fe}-\mathrm{P}$ bond lengths were elongated because of reduced $\pi$-backbonding from the central iron to the carbonyl and phosphite ligands. IR spectra of $[2] \mathrm{PF}_{6}$ and $[3] \mathrm{PF}_{6}$ consistently showed $\mathrm{C}-\mathrm{O}$ stretching bands of the carbonyl ligand at higher frequency $\left(1998 \mathrm{~cm}^{-1}\right.$ for $[2] \mathrm{PF}_{6}, 2011 \mathrm{~cm}^{-1}$ for $\left.[3] \mathrm{PF}_{6}\right)$ than those of $\mathbf{2}$ and $\mathbf{3}\left(1891 \mathrm{~cm}^{-1}\right.$ for $\mathbf{2}$, $1922 \mathrm{~cm}^{-1}$ for 3), respectively. EPR spectroscopy with [2]PF 6 and [3]PF 6 at room temperature (Figure S2) allowed comparison of the electron acceptability of the phosphorus ligands in $[1] \mathrm{PF}_{6}$ - [3]PF 6 . The complexes showed isotropic triplet signals at $g=2.042,2.044$ and 2.038 with hyperfine coupling constants, $1.5,1.4$ and $2.4 \mathrm{mT}$ for $[1] \mathrm{PF}_{6},[2] \mathrm{PF}_{6}$, and $[3] \mathrm{PF}_{6}$, respectively. The signals were ascribable to unpaired electrons of the central iron delocalized on two equivalent axial phosphorus ligands. Comparable coupling constants were previously reported for the other low-spin 17-electron iron(I) complexes with two phosphorus ligands, in which the major population of electrons was found on the central iron. ${ }^{65-67}$ This was also true of the present 
complexes while the significantly larger hyperfine coupling constants of $[3] \mathrm{PF}_{6}$ than those of $[1] \mathrm{PF}_{6}$ and $[2] \mathrm{PF}_{6}$ indicated the relatively higher electron acceptance of the phosphite ligand from the central iron, consistent with the weaker $\pi$-backbonding ability to the CO ligand in $\mathbf{3}$ and $[3] \mathrm{PF}_{6}$, inferred from IR spectroscopy. Theoretical data suggested that the $\mathrm{P}-\mathrm{O}$ anti-bonding component in the $\mathrm{P}(\mathrm{OEt})_{3}$ ligand was favorable to accept electrons from the central iron through Fe-P backbonding (vide infra). The electronic absorption spectra of [1] $\mathrm{PF}_{6}-[3] \mathrm{PF}_{6}$ in $\mathrm{CH}_{2} \mathrm{Cl}_{2}$ are shown in Figure 5. In a previous study, characteristic absorption bands of $[1] \mathrm{PF}_{6}$ at 588 and $862 \mathrm{~nm}$ were assigned to the LMCT excitation. ${ }^{52}$ These bands were also observed for [2] $\mathrm{PF}_{6}$ and $[3] \mathrm{PF}_{6}$. The absorption maxima were slightly blue-shifted in comparison to $[1] \mathrm{PF}_{6}(573,853 \mathrm{~nm}$ for $[2] \mathrm{PF}_{6}$ and $581,813 \mathrm{~nm}$ for $[3] \mathrm{PF}_{6}$ ), as were observed for the original complexes $\mathbf{1}$ - $\mathbf{3}$. Although the complexes $[1] \mathrm{PF}_{6}-[3] \mathrm{PF}_{6}$ were stable under dark conditions even in the coordinative solvent (acetonitrile) at $20{ }^{\circ} \mathrm{C}$ for $30 \mathrm{~min}$, prolonged incubation of [3] $\mathrm{PF}_{6}$ resulted in solvolysis cleavage of the Fe- $\mathrm{CO}$ bond, confirming the less stable $\mathrm{Fe}-\mathrm{CO}$ bond inferred from the longer $\mathrm{Fe}-\mathrm{CO}$ distance and higher $\mathrm{C}-\mathrm{O}$ stretching frequency.

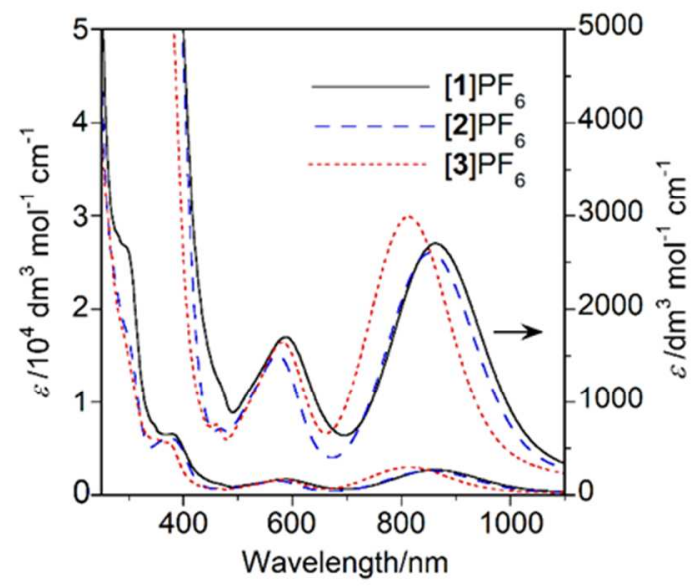

Figure 5. UV-Vis-NIR absorption spectra for [1] $\mathrm{PF}_{6}$ (black solid line), [2]PF 6 (blue dashed line), [3] $\mathrm{PF}_{6}$ (red dotted line) in $\mathrm{CH}_{2} \mathrm{Cl}_{2}$. 
Photoreaction of iron(III) carbonyl complexes. In a previous study, we found that light induced $\mathrm{CO}$ ligand-substitution of $[1] \mathrm{PF}_{6}$ in the coordinative solvent acetonitrile, although the substitution product was not amenable to detailed characterization of the reaction by either spectroscopic techniques or single crystal analysis. This problem was settled using tert-butyl isocyanide $\left({ }^{t} \mathrm{BuNC}\right)$, a stronger $\sigma$-donor ligand than acetonitrile as substituent for the $\mathrm{CO}$ ligand to produce the stable photo-product, trans-[Fe( $\left.\mathrm{PyBPT})\left(\mathrm{CN}^{t} \mathrm{Bu}\right)\left(\mathrm{PMe}_{2} \mathrm{Ph}\right)_{2}\right] \mathrm{PF}_{6}\left([5] \mathrm{PF}_{6}\right)(\mathrm{Scheme}$ 4). ${ }^{52}$ The ${ }^{1} \mathrm{H}$ and ${ }^{31} \mathrm{P}\left\{{ }^{1} \mathrm{H}\right\}$ NMR spectra and single crystal analysis with the one-electron-reduced form of $[5] \mathrm{PF}_{6}$ obtained by chemical reduction revealed that $\mathbf{5}$ conserved the overall conformation of $\mathbf{1}$ except for the coordination of isocyanide in the place of CO (Figure S3 and Table S2). ${ }^{51}$ This

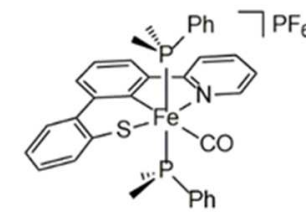

$[1] \mathrm{PF}_{6}$ $\operatorname{MeCN} \mid \begin{gathered}\text { visible light } \\ 0{ }^{\circ} \mathrm{C}\end{gathered}$

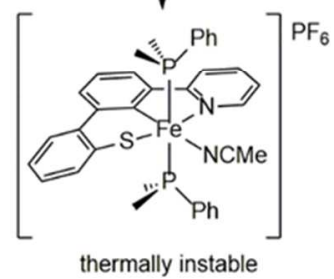

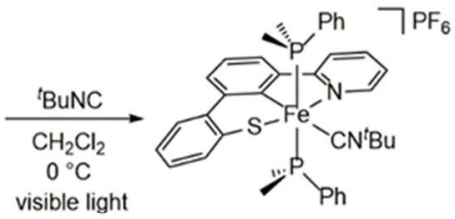

$[5] \mathrm{PF}_{6}$
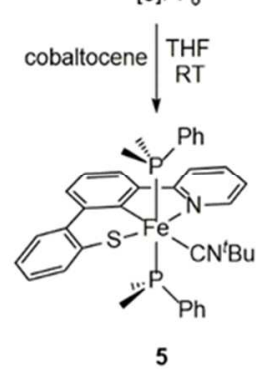

Scheme 4. Visible-light-induced ligand-substitution reactions of [1] $\mathrm{PF}_{6} \cdot{ }^{52}$

indicated that the photoreaction of $[1] \mathrm{PF}_{6}$ was accompanied by simple substitution of the $\mathrm{CO}$ ligand without removal or scrambling of other ligands. Photoreactions of $[2] \mathrm{PF}_{6}$ and $[3] \mathrm{PF}_{6}$ in acetonitrile, initiated by visible light irradiation, were traced by UV-Vis spectroscopy. Upon irradiation, $[2] \mathrm{PF}_{6}$ showed immediate spectral changes with isosbestic points at 415, 533, 641, and $777 \mathrm{~nm}$ (Figure 6a). Analogous changes were observed in the photoreaction of [1] $\mathrm{PF}_{6}$, 
indicating that complex [2] $\mathrm{PF}_{6}$ was capable of $\mathrm{CO}$ ligand substitution with a solvent molecule accompanied by no other structural changes or decomposition of the complex. ${ }^{52}$ By contrast, light irradiation to $[3] \mathrm{PF}_{6}$ (Figure $6 \mathrm{~b}$ ) resulted in a monotonous decrease in the specific bands of the complex, suggesting immediate decomposition of the resultant by photoreaction. Gas chromatography analysis (Figure S4) revealed quantitative release of $\mathrm{CO}$ from $[3] \mathrm{PF}_{6}(1.02 \pm$ 0.04 molecules of $\mathrm{CO}$ per $\left.[3] \mathrm{PF}_{6}\right)$ in the reaction. This indicated that no iron-carbonyl species were in the decomposition products. The monotonous spectral changes observed for $[3] \mathrm{PF}_{6}$ in acetonitrile were reproducible by photoreaction of either $[1] \mathrm{PF}_{6}$ or $[2] \mathrm{PF}_{6}$ in a non-coordinative solvent such
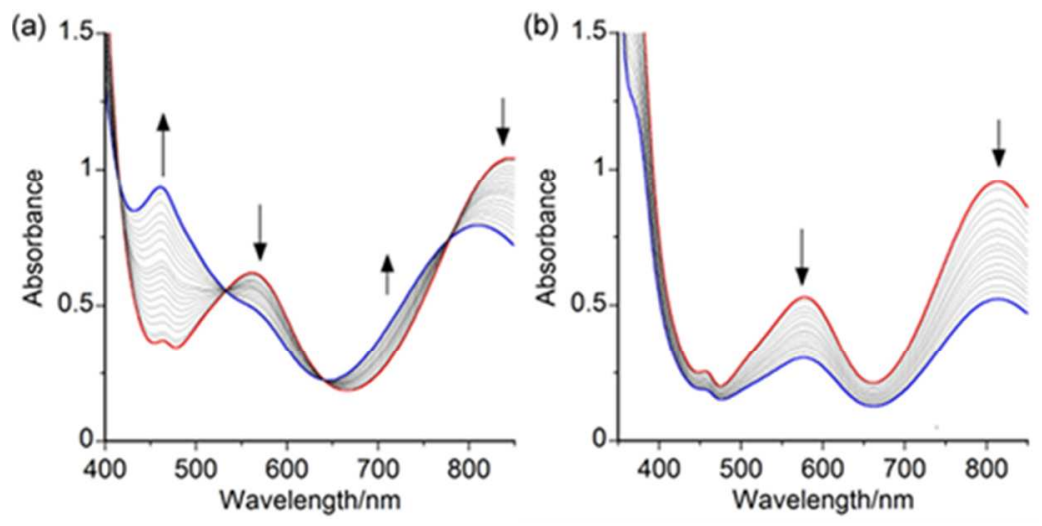

Figure 6. Spectral changes on visible-light irradiation of (a) $[2] \mathrm{PF}_{6}$ and (b) $[3] \mathrm{PF}_{6}$ in $\mathrm{CH}_{3} \mathrm{CN}$. The red and blue lines represent spectra before and after 5 min irradiation of the visible light, respectively.

as $\mathrm{CH}_{2} \mathrm{Cl}_{2}$. This suggested that coordination of the solvent molecule was crucial for stabilizing the initial products of the $\mathrm{CO}$ dissociation reaction from $[1] \mathrm{PF}_{6}-[3] \mathrm{PF}_{6}$. A plausible reason for the immediate decomposition of $[3] \mathrm{PF}_{6}$ upon photoreaction was the unstable coordination of acetonitrile in the place of $\mathrm{CO}$ due to weaker electron donation from the central iron(III) to acetonitrile, the $\pi$-acceptor ligand. Accordingly, the photoreaction of [3] $\mathrm{PF}_{6}$ in the presence of 
${ }^{t} \mathrm{BuNC}$ provided a more stable complex with the ${ }^{t} \mathrm{BuNC}$ ligand in place of $\mathrm{CO}$. Previous study with $[1] \mathrm{PF}_{6}$ demonstrated that the unstable 5-coordinated photoproduct in $\mathrm{CH}_{2} \mathrm{Cl}_{2}$ underwent disassembly to yield the phosphine, an equatorial ligand precursor, and iron(II) ion, through reductive elimination of the equatorial ligand under ambient conditions, where the iron(II) ion was possibly formed by air oxidation of initial iron product, iron(I) ion. Taking into consideration the quantitative release of $\mathrm{CO}$ and similar spectral changes to those of $[1] \mathrm{PF}_{6}$ in $\mathrm{CH}_{2} \mathrm{Cl}_{2}$, it would be rational to assume that the decomposition of [3] $\mathrm{PF}_{6}$ also involved reductive elimination of ligands from the unstable 5-coordinated species formed after $\mathrm{CO}$ dissociation by photo irradiation. ${ }^{1} \mathrm{H}-\mathrm{NMR}$ and ${ }^{31} \mathrm{P}-\mathrm{NMR}$ for the photoreaction products of $[3] \mathrm{PF}_{6}$ support the assumption (Figure S5).

Wavelength dependence of $\mathrm{CO}$ release from iron(III) carbonyl complexes. The quantum yields of photoinduced $\mathrm{CO}$ release were determined by the production of $\left[\mathrm{Fe}(\mathrm{phen})_{3}\right]^{2+}\left(\varepsilon_{509 \mathrm{~nm}}=\right.$ $1.1 \times 10^{4} \mathrm{dm}^{3} \mathrm{~mol}^{-1} \mathrm{~cm}^{-1}$ in $\left.\mathrm{CH}_{2} \mathrm{Cl}_{2}\right)$ in $\mathrm{CH}_{2} \mathrm{Cl}_{2}$ in the presence of phen. As the photoreaction of $[1] \mathrm{PF}_{6}-[3] \mathrm{PF}_{6}$ quantitatively released iron ion and $\mathrm{CO}$ molecule, colorimetric quantification of the iron ion is a reliable method for quantifying the $\mathrm{CO}$ released (Scheme 5). Representative

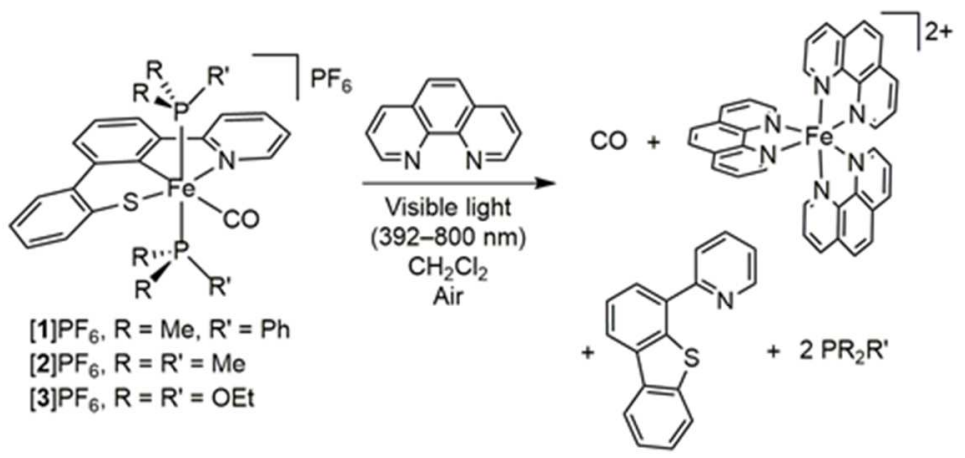

Scheme 5. Visible-light-responsive $\mathrm{CO}$ release from iron(III) carbonyl complexes in the presence of 1,10-phenanthroline. 
spectral changes of iron(III) carbonyl complexes with phen upon light irradiation are shown in Figure 7a. Apparent increases in absorbance at $509 \mathrm{~nm}$ with isosbestic points at 400 and $555 \mathrm{~nm}$ were observed. This corresponded to the disassembly of the complex by irradiation and consequent formation of $\left[\mathrm{Fe}(\mathrm{phen})_{3}\right]^{2+}$. Linear correlation was obtained for the amount of $\left[\mathrm{Fe}(\text { phen })_{3}\right]^{2+}$ produced and irradiation dose measured by a chemical actinometer over the complete wavelength range of the spectroscopic light (Figure 7b), and was used to evaluate the quantum yield of $\mathrm{CO}$ releases from the complexes. The quantum yields of photoinduced $\mathrm{CO}$ release from $[1] \mathrm{PF}_{6}-[3] \mathrm{PF}_{6}$ at different wavelengths are shown in Figures $7 \mathrm{c}-\mathrm{e}$, respectively. For all complexes, higher quantum yields were obtained at shorter wavelengths of the irradiated light and were more than $2 \%$ at $392 \mathrm{~nm}$. A prominent difference was found at longer wavelength. The phosphine complexes $[1] \mathrm{PF}_{6}$ and $[2] \mathrm{PF}_{6}$ showed no $\mathrm{CO}$ release at wavelengths longer than $500 \mathrm{~nm}$, while the phosphite 

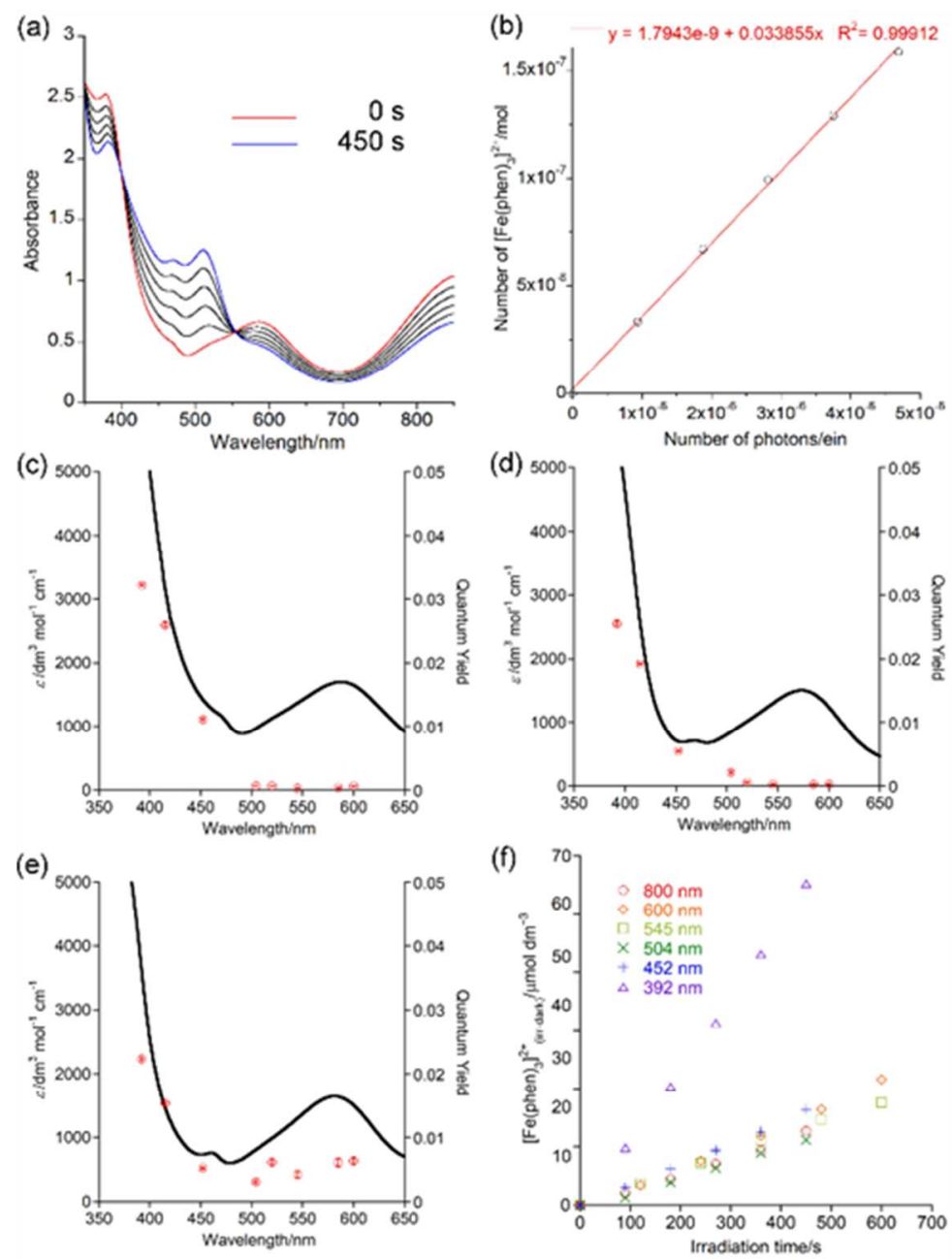

Figure 7. (a) Time course of the spectral changes of $[1] \mathrm{PF}_{6}$ in $\mathrm{CH}_{2} \mathrm{Cl}_{2}$ in the presence of 1,10 phenanthroline upon the irradiation of $392 \mathrm{~nm}$ wavelength light at $\mathrm{rt}$. (b) Plots of the number of $\left[\mathrm{Fe}(\mathrm{phen})_{3}\right]^{2+}$ calculated from spectral changes shown in (a) as a function of the number of absorbed photons by $[1] \mathrm{PF}_{6}$. A least-square line and fitting equation are also inserted in the figure. (c-e) The wavelength dependence of the quantum yields for CO-release reaction by (c) $[1] \mathrm{PF}_{6},(\mathrm{~d})[2] \mathrm{PF}_{6}$, and (e) $[3] \mathrm{PF}_{6}$. The quantum yields at each wavelength are plotted with red circles. Solid lines represent the electronic absorption spectra of $[1] \mathrm{PF}_{6}-[3] \mathrm{PF}_{6}$ in $\mathrm{CH}_{2} \mathrm{Cl}_{2}$. The quantum yields were determined as the average of at least three independent experiments. Error bars on the circles indicate standard errors. (f) Wavelength dependence of the rate of the 
photodecomposition of $[3] \mathrm{PF}_{6}$ in $\mathrm{CH}_{2} \mathrm{Cl}_{2}$. The values indicate the average of three independent experiments.

complex $[3] \mathrm{PF}_{6}$ retained its reactivity to light of $500-600 \mathrm{~nm}$ wavelength with a quantum yield of $0.7-1 \%$. Due to absence of an appropriate chemical actinometer, the quantum yield of $\mathrm{CO}$ release from $[3] \mathrm{PF}_{6}$ was not determined at wavelengths longer than $600 \mathrm{~nm}$. However, the quantitative production of $\left[\mathrm{Fe}(\text { phen })_{3}\right]^{2+}$ and $\mathrm{CO}$ from $[3] \mathrm{PF}_{6}$ was still detected when irradiated with light of wavelength $800 \mathrm{~nm}$. The absence of the production of $\left[\mathrm{Fe}(\mathrm{phen})_{3}\right]^{2+}$ and $\mathrm{CO}$ without irradiation confirmed that the light of wavelength $800 \mathrm{~nm}$ was the source for photoreaction of $[3] \mathrm{PF}_{6}$. The production rate of $[\mathrm{Fe}(\text { phen })]^{3+}$ at $800 \mathrm{~nm}$ was comparable to those at other wavelengths examined in this study, except for $392 \mathrm{~nm}$ (Figure $7 \mathrm{f}$ ). As the optical intensity of the light used in the study (xenon light equipped in an ordinary fluorescent spectrometer) varied according to wavelength, it was premature to deduce the quantum yield at $800 \mathrm{~nm}$ by comparing the $\left[\mathrm{Fe}(\text { phen })_{3}\right]^{2+}$ production rates. Nevertheless, the results demonstrated that $[3] \mathrm{PF}_{6}$ was sufficiently sensitive to $800 \mathrm{~nm}$ wavelength light emitted from an ordinary spectrometer to release

$\mathrm{CO}$ with similar efficiency to those at shorter wavelengths. BODIPY-based photo-CORMs, which were reported to be responsive to light of the NIR optical range, showed quantum yields of $0.001 \%$ at $505 \mathrm{~nm}$ for CO release. ${ }^{29}$ This CORM was stable under irradiation of NIR light from a fluorescence spectrometer. Significant discrepancy between the quantum yield for CO release from $[3] \mathrm{PF}_{6}$ and the absorption spectrum in the longer wavelength region implied that the apparent absorption bands were not associated with the photochemistry of CO release. This will be discussed in the next section. 
DFT calculations. Quantum chemical calculations were performed using density functional theory (DFT) at the uB3LYP/6-311+G(d,p) level to obtain insight into the effect of the phosphite ligand on the extended photosensitivity of $[3] \mathrm{PF}_{6}$ to the long wavelength region. As was reported for $[1] \mathrm{PF}_{6}$ in the previous study, the crystal structures of [2] $\mathrm{PF}_{6}$ and $[3] \mathrm{PF}_{6}$ were reproduced in the optimized structures of $[2]^{+}$and $[3]^{+}$, respectively (Figures S6). The spin densities in $[2]^{+}$and $[3]^{+}$(Figure 8) were mainly located on the iron and thiophenolate moieties with small contributions

(a)

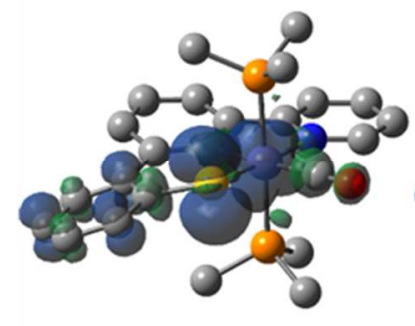

(b)

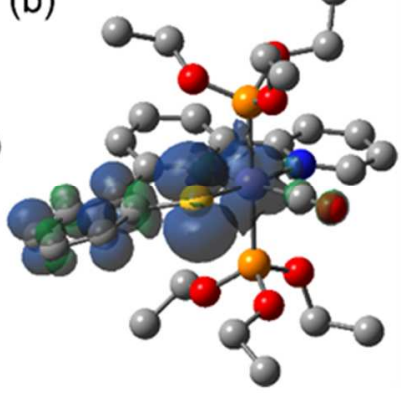

Figure 8. Spin density diagrams (isovalue $=0.0015)$ of $(a)[2]^{+}$and (b) $[3]^{+}$calculated by DFT at the $\mathrm{uB3}$ LYP/6-311+G(d,p) level.

from phosphorus ligands. These locations corresponded to the HOMO of $\alpha$-spin orbitals and LUMO of $\beta$-spin orbitals. The same results were obtained for $[1]^{+52}$ The Mulliken atomic spin density (Table S3) calculated at the central iron in $[3]^{+}(0.734)$ was smaller than those in the phosphine complexes $\left(0.964\right.$ for $[1]^{+}$and 0.888 for $\left.[2]^{+}\right)$, coincident with the trend of the ability to donate electrons to the CO ligand, inferred from the results of IR spectroscopy. Timedependent DFT (TD-DFT) calculations reproduced the features of the absorption spectra of $[2] \mathrm{PF}_{6}$ and $[3] \mathrm{PF}_{6}$ (Figure 9, S17 - 18). Energy diagrams and shapes of selected MOs involved in low-energy 

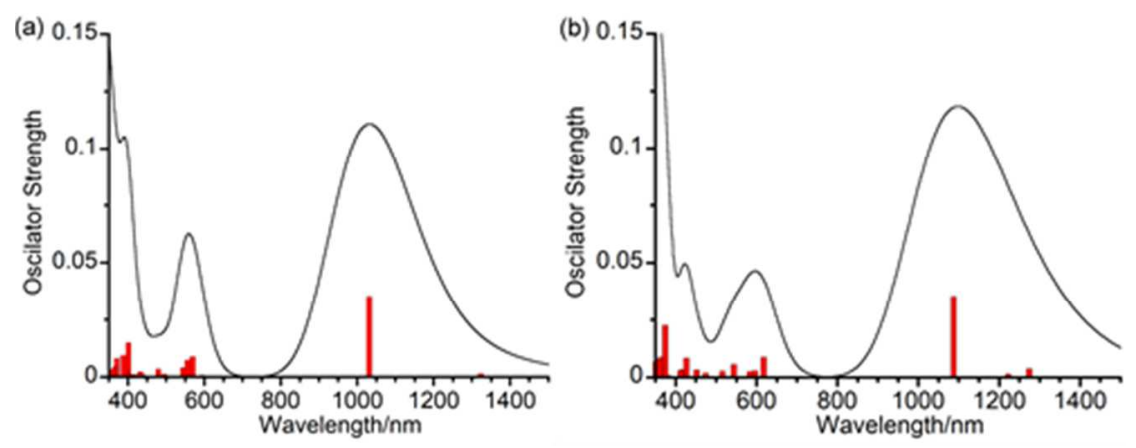

Figure 9. Predicted electronic absorption spectra of (a) $[\mathbf{2}]^{+}$and (b) $[\mathbf{3}]^{+}$calculated by TD-DFT at $\mathrm{uB} 3 \mathrm{LYP} / 6-311 \mathrm{~g}+(\mathrm{d}, \mathrm{p})$ level.

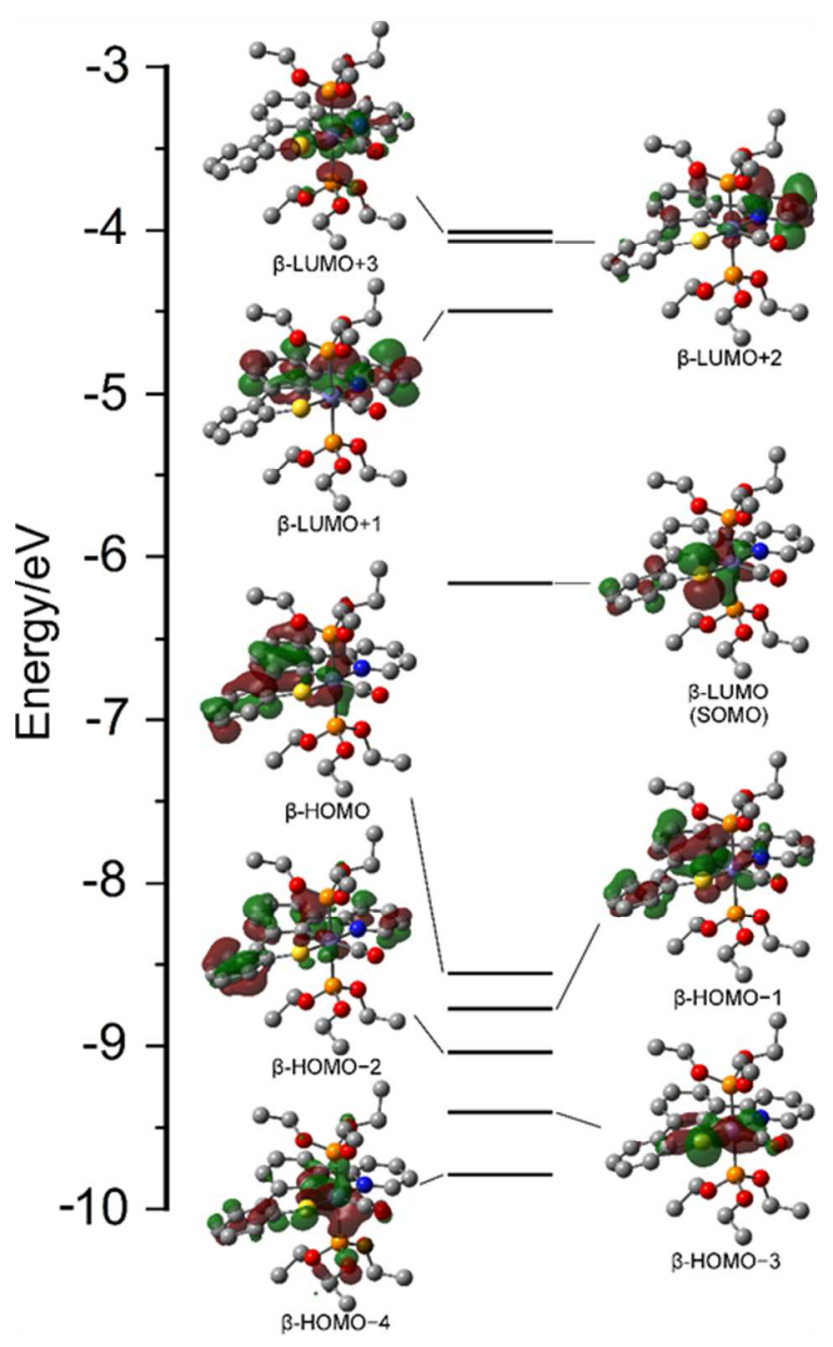


Figure 10. Selected frontier and near-frontier orbital energy diagram of $[3]^{+}$. The prominent MOs involved in low energy transitions are also shown.

transitions in $[3]^{+}$are shown in Figure 10. The intense transitions of $[2]^{+}$and $[3]^{+}$in the NIR region $\left(1030 \mathrm{~nm}\right.$ for $[2]^{+}, 1087 \mathrm{~nm}$ for $\left.[3]^{+}\right)$were assigned to LMCT transitions from orbitals spread over the biphenyl thiolate moiety ( $\beta$-HOMO-1 in Figure 10$)$ to the iron $\mathrm{d} \pi$ orbitals $(\beta$ LUMO $=$ SOMO). The same transition was found at $951 \mathrm{~nm}$ for $[1]^{+52}$ The energy discrepancies in transitions between the experimental and calculated data, particularly in the NIR region, could be a reflection of the strong charge-transfer characters of these transitions, as TD-DFT calculations tend to underestimate the excitation energies of charge transfer transitions. ${ }^{68}$ Two moderate transitions around $600 \mathrm{~nm}\left(568\right.$ and $555 \mathrm{~nm}$ for $[2]^{+}, 617$ and $543 \mathrm{~nm}$ for $\left.[3]^{+}\right)$were also assigned to LMCT transitions from the biphenyl pyridine $\pi$-system ( $\beta$-HOMO- 2 ) to ironcentered $\beta$-LUMO and from the thiolate-centered $\beta$-HOMO to iron $d \sigma^{*}$ orbitals. These LMCT transitions were unlikely excitations for $\mathrm{CO}$ release from the complexes, as the major molecular orbitals concerned with these transitions did not participate in $\mathrm{Fe}-\mathrm{CO}$ bonding (occupied) or antibonding (unoccupied) interactions. The TD-DFT calculation predicted the presence of weak $\mathrm{d}-\mathrm{d}$ transition bands behind the LMCT bands. In $[3]^{+}$, the transition from $\beta-\mathrm{HOMO}-3$ to $\beta$ LUMO (SOMO) was predicted at $1222 \mathrm{~nm}$. $\beta$-HOMO-3 showed obvious Fe-CO $\pi$-bonding character, and the SOMO was perpendicular to the Fe-CO bond. Therefore, depopulation of the Fe-CO $\pi$-bonding orbital was induced by the $d \pi-d \pi$ transition process, which destabilized the weak $\mathrm{Fe}-\mathrm{CO} \pi$-backbonding in $[3] \mathrm{PF}_{6}$, resulting in $\mathrm{CO}$ release triggered by $\mathrm{d} \pi$ - $\mathrm{d} \pi$ excitation. $\mathrm{A}$ similar mechanism was expected for $\mathrm{d}$-d transitions from $\beta$-HOMO-3 to $\beta$-LUMO $+3\left(\mathrm{~d} \sigma^{*}(\mathrm{Fe})\right.$ ) $(596 \mathrm{~nm})$ and from $\beta$-HOMO-4 (bonding $\mathrm{d} \pi(\mathrm{Fe}-\mathrm{CO}))$ to $\beta$-LUMO $(583 \mathrm{~nm})$. Although analogous transition modes in the NIR and visible regions were also supposed for phosphine 
complexes $[\mathbf{1}]^{+}$and $[\mathbf{2}]^{+}$, experimental results revealed the incompetence of $[1] \mathrm{PF}_{6}$ and $[2] \mathrm{PF}_{6}$ toward $\mathrm{CO}$ release responding to wavelengths longer than $500 \mathrm{~nm}$. This difference emphasized the importance of weaker $\mathrm{Fe}-\mathrm{CO}$ bonds in $[3] \mathrm{PF}_{6}$ caused by stronger $\pi$-acceptability of $\mathrm{P}(\mathrm{OEt})_{3}$ ligand to release $C O$ in response to the less effective $d \pi-d \pi$ transition. The overlap of $d \pi-d \pi$ transition bands for $\mathrm{CO}$ release with strong LMCT bands caused discrepancy between the quantum yield of CO release and apparent light absorbance in the longer wavelength region. The red shift of transitions related to Fe-CO bond cleavage was also predicted in the DFT calculation of $[3] \mathrm{PF}_{6}$. The $\pi$-backbonding interaction of phosphorus ligands with an iron d-orbital stabilized the SOMO level of the complexes while the $\pi$-backbonding interaction was orthogonal to the $\mathrm{Fe}-\mathrm{CO} \pi$-bonding orbitals. As a result, the transition energies from $\mathrm{d} \pi(\mathrm{Fe}-\mathrm{CO})$ to $\mathrm{d} \pi(\mathrm{SOMO})$ ( $\beta$-HOMO-3 or $\beta$-HOMO-1 to $\beta$-LUMO) were reduced by the coordination of the phosphorus ligands. This effect was more favorable to $[3] \mathrm{PF}_{6}$ than $[1] \mathrm{PF}_{6}$ and $[2] \mathrm{PF}_{6}$ because of the stronger $\pi$-backbonding character of the phosphite ligand than the phosphine ligands. In addition to the above $\mathrm{d} \pi$ - $\mathrm{d} \pi$ transitions, more efficient $\mathrm{CO}$ dissociation by transition from $\mathrm{d} \pi(\mathrm{Fe}-\mathrm{CO})$ orbitals to $\mathrm{d} \sigma^{*}(\mathrm{Fe}-\mathrm{CO})$ or $\mathrm{d} \pi *(\mathrm{Fe}-\mathrm{CO})$ orbital was deduced from the calculation. This was consistent with the higher quantum yields observed at $392-452 \mathrm{~nm}$ for $[1] \mathrm{PF}_{6}-[3] \mathrm{PF}_{6}($ Figures $7(\mathrm{c})-(\mathrm{e}))$.

\section{CONCLUSION}

We describe the photoresponsive CO-releasing ability of newly synthesized iron(III) carbonyl complexes trans-[Fe(PyBPT $\left.)(\mathrm{CO})\left(\mathrm{PR}_{2} \mathrm{R}^{\prime}\right)_{2}\right] \mathrm{PF}_{6}\left(\mathrm{R}=\mathrm{Me}, \mathrm{R}^{\prime}=\mathrm{Ph}\right.$ for $[1] \mathrm{PF}_{6} ; \mathrm{R}=\mathrm{R}^{\prime}=\mathrm{Me}$ for $[2] \mathrm{PF}_{6} ; \mathrm{R}=\mathrm{R}^{\prime}=\mathrm{OEt}$ for $\left.[3] \mathrm{PF}_{6}\right)$. Despite the resemblance of the absorption spectra of all complexes, only $[3] \mathrm{PF}_{6}$ with $\mathrm{P}(\mathrm{OEt})_{3}$ ligands exhibited extended light sensitivity covering the entire visible region and the edge of the NIR region $(\sim 390-800 \mathrm{~nm})$ to release CO with reasonable quantum yields. The observed trends in the $\mathrm{C}-\mathrm{O}$ stretching frequencies and hyperfine 
coupling constants of EPR spectra $\left([3] \mathrm{PF}_{6}>[2] \mathrm{PF}_{6} \approx[1] \mathrm{PF}_{6}\right)$ indicated that phosphite was more effective than phosphines in accepting electrons from the central iron and weakening the $\mathrm{Fe}-\mathrm{CO}$ bond through $\pi$-backbonding. The moderately weakened Fe-CO bond acquired sensitivity to $\mathrm{d} \pi$ $\mathrm{d} \pi$ excitation, which included depopulation of the Fe-CO bonding orbital, but was usually less usable for cleaving the $\mathrm{Fe}-\mathrm{CO}$ bond. Quantum chemical calculations for the complexes predicted stabilization of the SOMO level by $\pi$-backbonding from the central iron to phosphorous ligands. The $\mathrm{P}(\mathrm{OEt})_{3}$ ligand with stronger $\pi$-acceptability was a possible effector in reducing energy of the $\mathrm{d} \pi-\mathrm{d} \pi$ excitation to render $\mathrm{CO}$ release from $[3] \mathrm{PF}_{6}$ responsive to lower energy light. Overlap of the $\mathrm{d} \pi-\mathrm{d} \pi$ transition band with strong LMCT bands obscured these photochemical properties from the apparent spectrum and led to the underestimation of the quantum yield for CO release in the combined wavelength region. At the moment, there is no appropriate molecular design for shedding the influences of LMCT bands on the $\mathrm{CO}$ release reaction. Nevertheless, the results obtained in this study demonstrated that $\mathrm{d} \pi-\mathrm{d} \pi$ photo-excitation to depopulate the $\mathrm{Fe}-\mathrm{CO}$ bonding orbital could be a promising mode for $\mathrm{CO}$ dissociation from iron-based photo-CORMs in long wavelength regions extending to NIR light. As the present complexes showed only slight solubility in aqueous media, biological assays using cell lines were not performed. DFT calculation, however, supposed that introducing some substituents on the equatorial pyridyl group had little influence on the electronic structure of $[3] \mathrm{PF}_{6}$. This is a promising clue for molecular design to afford the water solubility of the complex.

\section{ASSOCIATED CONTENT}

\section{Supporting Information}


The Supporting Information is available free of charge on the ACS Publications website. NMR spectra, EPR spectra, UV-visible spectra, Gas chromatography data, summary tables of X-ray data, Results of DFT calculation, and Crystallography data for 2, $[2] \mathrm{PF}_{6}, \mathbf{3},[3] \mathrm{PF}_{6}, \mathbf{4}$, and 5 in CIF format.

\section{AUTHOR INFORMATION}

\section{Corresponding Author}

*H.N. e-mail: hnakajima@osaka-cu.ac.jp

*M.H. e-mail: mhiro@kanagawa-u.ac.jp

\section{ORCID}

Hiroshi Nakaijma: 0000-0002-0079-1274

Masakazu Hirotsu: 0000-0001-9010-1945

\section{Present Address}

M.H.: Department of Chemistry, Faculty of Science, Kanagawa University, 2946 Tsuchiya, Hiratsuka-shi, Kanagawa 259-1293, Japan

\section{Notes}

The authors declare no competing financial interest.

\section{ACKNOWLEDGMENT}

This work was supported by JSPS KAKENHI Grant Numbers JP17J11464 and JP16K05729, and a Grant-in-Aid for Strategic Research of Osaka City University.

\section{ABBREVIATIONS USED}


CORM, CO-releasing molecules; EPR, electron paramagnetic resonance; HOMO, Highestoccupied molecular orbital; LMCT, ligand-to-metal charge-transfer; LUMO, lowest-unoccupied molecular orbital; NIR, near infrared; SOMO, Singly-occupied molecular orbital; phen, 1,10phenanthroline;

\section{REFERENCES}

1. Von Burg, R. Carbon monoxide. J. Appl. Toxicol. 1999, 19 (5), 379-386.

2. Weaver, L. K. Carbon Monoxide Poisoning. N. Engl. J. Med. 2009, 360 (12), 1217-1225.

3. Tenhunen, R.; Marver, H. S.; Schmid, R. Enzymatic conversion of heme to bilirubin by microsomal heme oxygenase. Proc. Natl. Acad. Sci. U. S. A. 1968, 61 (2), 748-\&.

4. Ryter, S. W.; Alam, J.; Choi, A. M. K. Heme oxygenase-1/carbon monoxide: From basic science to therapeutic applications. Physiol. Rev. 2006, 86 (2), 583-650.

5. Abraham, N. G.; Kappas, A. Pharmacological and clinical aspects of heme oxygenase. Pharmacol. Rev. 2008, 60 (1), 79-127.

6. Wilkinson, W. J.; Kemp, P. J. Carbon monoxide: an emerging regulator of ion channels. J. Physiol.-London 2011, 589 (13), 3055-3062.

7. Oliveira, S. R.; Queiroga, C. S. F.; Vieira, H. L. A. Mitochondria and carbon monoxide: cytoprotection and control of cell metabolism - a role for $\mathrm{Ca}^{2+}$ ? J. Physiol.-London 2016, 594 (15), 4131-4138.

8. Choi, Y. K.; Maki, T.; Mandeville, E. T.; Koh, S. H.; Hayakawa, K.; Arai, K.; Kim, Y. M.; Whalen, M. J.; Xing, C. H.; Wang, X. Y.; Kim, K. W.; Lo, E. H. Dual effects of carbon 
monoxide on pericytes and neurogenesis in traumatic brain injury. Nat. Med. 2016, 22 (11), 1335-1341.

9. Magierowska, K.; Magierowski, M.; Surmiak, M.; Adamski, J.; Mazur-Bialy, A. I.; Pajdo, R.; Sliwowski, Z.; Kwiecien, S.; Brzozowski, T. The Protective Role of Carbon Monoxide (CO) Produced by Heme Oxygenases and Derived from the CO-Releasing Molecule CORM-2 in the Pathogenesis of Stress-Induced Gastric Lesions: Evidence for Non-Involvement of Nitric Oxide (NO). Int. J. Mol. Sci. 2016, 17 (4),

10. Peng, Y. J.; Zhang, X. L.; Gridina, A.; Chupikova, I.; McCormick, D. L.; Thomas, R. J.; Scammell, T. E.; Kim, G.; Vasavda, C.; Nanduri, J.; Kumar, G. K.; Semenza, G. L.; Snyder, S. H.; Prabhakar, N. R. Complementary roles of gasotransmitters $\mathrm{CO}$ and $\mathrm{H}_{2} \mathrm{~S}$ in sleep apnea. Proc. Natl. Acad. Sci. U. S. A. 2017, 114 (6), 1413-1418.

11. Motterlini, R.; Clark, J. E.; Foresti, R.; Sarathchandra, P.; Mann, B. E.; Green, C. J. Carbon monoxide-releasing molecules - Characterization of biochemical and vascular activities. Circ.Res. 2002, 90 (2), E17-E24.

12. Chaves-Ferreira, M.; Albuquerque, I. S.; Matak-Vinkovic, D.; Coelho, A. C.; Carvalho, S. M.; Saraiva, L. M.; Romao, C. C.; Bernardes, G. J. L. Spontaneous CO Release from Ru$\mathrm{II}(\mathrm{CO})_{2}$-Protein Complexes in Aqueous Solution, Cells, and Mice. Angew. Chem.-Int. Edit. 2015, $54(4), 1172-1175$.

13. Schatzschneider, U. Novel lead structures and activation mechanisms for CO-releasing molecules (CORMs). Br. J. Pharmacol. 2015, 172 (6), 1638-1650. 
14. Kautz, A. C.; Kunz, P. C.; Janiak, C. CO-releasing molecule (CORM) conjugate systems. Dalton Trans. 2016, 45 (45), 18045-18063.

15. Fairlamb, I. J. S.; Lynam, J. M.; Moulton, B. E.; Taylor, I. E.; Duhme-Klair, A. K.; Sawle, P.; Motterlini, R. $\eta^{1}$-2-pyrone metal carbonyl complexes as CO-releasing molecules (CORMs): A delicate balance between stability and CO liberation. Dalton Trans. 2007, (33), 36033605.

16. Gonzalez, M. A.; Fry, N. L.; Burt, R.; Davda, R.; Hobbs, A.; Mascharak, P. K. Designed Iron Carbonyls as Carbon Monoxide (CO) Releasing Molecules: Rapid CO Release and Delivery to Myoglobin in Aqueous Buffer, and Vasorelaxation of Mouse Aorta. Inorg. Chem. 2011, 50 (7), 3127-3134.

17. Romanski, S.; Kraus, B.; Schatzschneider, U.; Neudorfl, J. M.; Amslinger, S.; Schmalz, H. G. Acyloxybutadiene Iron Tricarbonyl Complexes as Enzyme-Triggered CO-Releasing Molecules (ET-CORMs). Angew. Chem.-Int. Edit. 2011, 50 (10), 2392-2396.

18. Wrighton, M. S.; Ginley, D. S.; Morse, D. L. Technique for determination of absolute emission quantum yields of powdered samples. J. Phys. Chem. 1974, 78 (22), 2229-2233.

19. Trushin, S. A.; Fuss, W.; Kompa, K. L.; Schmid, W. E. Femtosecond dynamics of $\mathrm{Fe}(\mathrm{CO})_{5}$ photodissociation at $267 \mathrm{~nm}$ studied by transient ionization. J. Phys. Chem. A 2000, 104 (10), 1997-2006.

20. Wernet, P.; Kunnus, K.; Josefsson, I.; Rajkovic, I.; Quevedo, W.; Beye, M.; Schreck, S.; Grubel, S.; Scholz, M.; Nordlund, D.; Zhang, W.; Hartsock, R. W.; Schlotter, W. F.; Turner, J. J.; Kennedy, B.; Hennies, F.; de Groot, F. M. F.; Gaffney, K. J.; Techert, S.; Odelius, M.; 
Fohlisch, A. Orbital-specific mapping of the ligand exchange dynamics of $\mathrm{Fe}(\mathrm{CO})_{5}$ in solution. Nature 2015, 520 (7545), 78-81.

21. Rimmer, R. D.; Richter, H.; Ford, P. C. A Photochemical Precursor for Carbon Monoxide Release in Aerated Aqueous Media. Inorg. Chem. 2010, 49 (3), 1180-1185.

22. Pierri, A. E.; Pallaoro, A.; Wu, G.; Ford, P. C. A Luminescent and Biocompatible PhotoCORM. J. Am. Chem. Soc. 2012, 134 (44), 18197-18200.

23. König, K. Multiphoton microscopy in life sciences. J. Microsc. 2000, 200, 83-104.

24. Kianfar, E.; Apaydin, D. H.; Knor, G. Spin-Forbidden Excitation: A New Approach for Triggering Photopharmacological Processes with Low-Intensity NIR Light. ChemPhotoChem 2017, $1(9), 378-382$.

25. Kottelat, E.; Zobi, F. Visible Light-Activated PhotoCORMs. Inorganics 2017, 5 (2),

26. Li, Z.; Pierri, A. E.; Huang, P. J.; Wu, G.; Iretskii, A. V.; Ford, P. C. Dinuclear PhotoCORMs: Dioxygen-Assisted Carbon Monoxide Uncaging from Long-Wavelength Absorbing Metal-Metal-Bonded Carbonyl Complexes. Inorg. Chem. 2017, 56 (11), 6094-6104.

27. Chakraborty, I.; Carrington, S. J.; Mascharak, P. K. Design Strategies To Improve the Sensitivity of Photoactive Metal Carbonyl Complexes (photoCORMs) to Visible Light and Their Potential as CO-Donors to Biological Targets. Accounts Chem. Res. 2014, 47 (8), 2603-2611.

28. Kottelat, E.; Ruggi, A.; Zobi, F. Red-light activated photoCORMs of Mn(I) species bearing electron deficient 2,2 '-azopyridines. Dalton Trans. 2016, 45 (16), 6920-6927. 
29. Palao, E.; Slanina, T.; Muchova, L.; Solomek, T.; Vitek, L.; Klan, P. Transition-MetalFree CO-Releasing BODIPY Derivatives Activatable by Visible to NIR Light as Promising Bioactive Molecules. J. Am. Chem. Soc. 2016, 138 (1), 126-133.

30. Neal, A. P.; Guilarte, T. R. Mechanisms of lead and manganese neurotoxicity. Toxicol. Res. 2013, 2 (2), 99-114.

31. Kafritsa, Y.; Fell, J.; Long, S.; Bynevelt, M.; Taylor, W.; Milla, P. Long term outcome of brain manganese deposition in patients on home parenteral nutrition. Arch. Dis. Child. 1998, 79 (3), 263-265.

32. Katsuragi, T.; Iseki, E.; Kosaka, K.; Koyano, S.; Iwabuchi, K. Cerebrospinal fluid manganese concentrations in patients with symmetric pallidal hyperintensities on $\mathrm{T} 1$ weighted MRI. J. Neurol. Neurosurg. Psychiatry 1999, 66 (4), 551-552.

33. Nagatomo, S.; Umehara, F.; Hanada, K.; Nobuhara, Y.; Takenaga, S.; Arimura, K.; Osame, M. Manganese intoxication during total parenteral nutrition: report of two cases and review of the literature. J. Neurol. Sci. 1999, 162 (1), 102-105.

34. Hentze, M. W.; Caughman, S. W.; Rouault, T. A.; Barriocanal, J. G.; Dancis, A.; Harford, J. B.; Klausner, R. D. Identification of the iron-responsive element for the translational regulation of human ferritin messenger-RNA. Science 1987, 238 (4833), 1570-1573.

35. Casey, J. L.; Hentze, M. W.; Koeller, D. M.; Caughman, S. W.; Rouault, T. A.; Klausner, R. D.; Harford, J. B. Iron-responsive elements - regulatory RNA sequences that control messenger-RNA levels and translation. Science 1988, 240 (4854), 924-928. 
36. Wang, J. A.; Pantopoulos, K. Regulation of cellular iron metabolism. Biochem. J. 2011, 434, 365-381.

37. Jackson, C. S.; Schmitt, S.; Dou, Q. P.; Kodanko, J. J. Synthesis, Characterization, and Reactivity of the Stable Iron Carbonyl Complex $\mathrm{Fe}(\mathrm{CO})\left(\mathrm{N}_{4} \mathrm{Py}\right)\left(\mathrm{ClO}_{4}\right)_{2}$ : Photoactivated Carbon Monoxide Release, Growth Inhibitory Activity, and Peptide Ligation. Inorg. Chem. 2011, 50 (12), 5336-5338.

38. Velasquez, V. P. L.; Jazzazi, T. M. A.; Malassa, A.; Gorls, H.; Gessner, G.; Heinemann, S. H.; Westerhausen, M. Derivatives of Photosensitive CORM-S1-CO Complexes of Iron and Ruthenium with the $(\mathrm{OC})_{2} \mathrm{M}\left(\mathrm{S}-\mathrm{C}-\mathrm{C}-\mathrm{NH}_{2}\right)_{2}$ Fragment. Eur. J. Inorg. Chem. 2012, (7), 1072-1078.

39. Jazzazi, T. M. A.; Gorls, H.; Gessner, G.; Heinemann, S. H.; Westerhausen, M. Photosensitive iron(II)-based CO-releasing molecules (CORMs) with vicinal amino and diphenylphosphino substituted chelating ligands. J. Organomet. Chem. 2013, 733, 63-70.

40. Poh, H. T.; Sim, B. T.; Chwee, T. S.; Leong, W. K.; Fan, W. Y. The Dithiolate-Bridged Diiron Hexacarbonyl Complex $\left.\mathrm{Na}_{2}\left[\mu-\mathrm{SCH}_{2} \mathrm{CH}_{2} \mathrm{COO}\right) \mathrm{Fe}(\mathrm{CO})_{3}\right]^{2}$ as a Water-Soluble PhotoCORM. Organometallics 2014, 33 (4), 959-963.

41. Hewison, L.; Johnson, T. R.; Mann, B. E.; Meijer, A.; Sawle, P.; Motterlini, R. A reinvestigation of $\left[\mathrm{Fe}(\mathrm{L} \text {-cysteinate })_{2}(\mathrm{CO})_{2}\right]^{2-}$ : an example of non-heme $\mathrm{CO}$ coordination of possible relevance to CO binding to ion channel receptors. Dalton Trans. 2011, 40 (33), 83288334. 
42. Kretschmer, R.; Gessner, G.; Gorls, H.; Heinemann, S. H.; Westerhausen, M. Dicarbonyl-bis(cysteamine)iron(II) A light induced carbon monoxide releasing molecule based on iron (CORM-S1). J. Inorg. Biochem. 2011, 105 (1), 6-9.

43. Klein, M.; Neugebauer, U.; Gheisari, A.; Malassa, A.; Jazzazi, T. M. A.; Froehlich, F.; Westerhausen, M.; Schmitt, M.; Popp, J. IR Spectroscopic Methods for the Investigation of the CO Release from CORMs. J. Phys. Chem. A 2014, 118 (29), 5381-5390.

44. Li, W. P.; Su, C. H.; Tsao, L. C.; Chang, C. T.; Hsu, Y. P.; Yeh, C. S. Controllable CO Release Following Near Infrared Light-Induced Cleavage of Iron Carbonyl Derivatized Prussian Blue Nanoparticles for CO-Assisted Synergistic Treatment. ACS Nano 2016, 10 (12), 1102711036.

45. Ou, J.; Zheng, W. H.; Xiao, Z. Y.; Yan, Y. P.; Jiang, X. J.; Dou, Y.; Jiang, R.; Liu, X. M. Core-shell materials bearing iron(II) carbonyl units and their CO-release via an upconversion process. J. Mat. Chem. B 2017, 5 (41), 8161-8168.

46. Meyer, H.; Brenner, M.; Hofert, S. P.; Knedel, T. O.; Kunz, P. C.; Schmidt, A. M.; Hamacher, A.; Kassack, M. U.; Janiak, C. Synthesis of oxime-based CO-releasing molecules, CORMs and their immobilization on maghemite nanoparticles for magnetic-field induced $\mathrm{CO}$ release. Dalton Trans. 2016, 45 (18), 7605-7615.

47. Meyer, H.; Winkler, F.; Kunz, P.; Schmidt, A. M.; Hamacher, A.; Kassack, M. U.; Janiak, C. Stabilizing alginate confinement and polymer coating of CO-releasing molecules supported on iron oxide nanoparticles to trigger the $\mathrm{CO}$ release by magnetic heating. Inorg. Chem. 2015, 54 (23), 11236-11246. 
48. Nakae, T.; Hirotsu, M.; Kinoshita, I. Di- and mononuclear iron complexes of N,C,Stridentate ligands containing an aminopyridyl group: effect of the pendant amine site on catalytic properties for proton reduction. Organometallics 2015, 34 (16), 3988-3997.

49. Santo, K.; Hirotsu, M.; Kinoshita, I. Formation, reactivity and redox properties of carbonand sulfur-bridged diiron complexes derived from dibenzothienyl Schiff bases: effect of $N, N$ and N,P-chelating moieties. Dalton Trans. 2015, 44 (9), 4155-4166.

50. Matsunaga, T.; Kinoshita, I.; Hirotsu, M. Carbon-sulfur bond cleavage reactions of quinolyl-substituted thiophenes with iron carbonyls. Organometallics 2017, 36 (11), 2228-2236.

51. Hirotsu, M.; Santo, K.; Tsuboi, C.; Kinoshita, I. Diiron carbonyl complexes bearing an $N, C, S$-pincer ligand: reactivity toward phosphines, heterolytic $\mathrm{Fe}-\mathrm{Fe}$ cleavage, and electrocatalytic proton reduction. Organometallics 2014, 33 (16), 4260-4268.

52. Nakae, T.; Hirotsu, M.; Aono, S.; Nakajima, H. Visible-light-induced release of CO by thiolate iron(III) carbonyl complexes bearing N,C,S-pincer ligands. Dalton Trans. 2016, 45 (41), 16153-16156.

53. Sharp, D. W. A. Complex florides.11. The preparation and infrared spectra of tri-paratolylaminium salts. J. Chem. Soc. 1957, (DEC), 4804-4809.

54. Bouzaid, J.; Schultz, M.; Lao, Z.; Bartley, J.; Bostrom, T.; McMurtrie, J. Supramolecular selection in molecular alloys. Cryst. Growth Des. 2012, 12 (8), 3906-3916.

55. Wegner, E. E.; Adamson, A. W. Photochemistry of complex ions .3. Absolute quantum yields for photolysis of some aqueous chromium(3) complexes . Chemical actinometry in long wavelength visible region. J. Am. Chem. Soc. 1966, 88 (3), 394-\&. 
56. Szychlinski, J.; Bilski, P.; Martuszewski, K.; Blazejowski, J. Complementary study on the use of the potassium reinecke salt as a chemical actinometer. Analyst 1989, 114 (6), 739-741.

57. CrystalClear Rigaku Corporation: 2007.

58. Farrugia, L. J. WinGX and ORTEP for Windows: an update. J. Appl. Crystallogr. 2012, $45,849-854$.

59. Altomare, A.; Burla, M. C.; Camalli, M.; Cascarano, G. L.; Giacovazzo, C.; Guagliardi, A.; Moliterni, A. G. G.; Polidori, G.; Spagna, R. SIR97: a new tool for crystal structure determination and refinement. J. Appl. Crystallogr. 1999, 32, 115-119.

60. Sheldrick, G. M. A short history of SHELX. Acta Crystallogr. Sect. A 2008, 64, 112-122.

61. Frisch MJ, T. G., Schlegel HB, Scuseria GE, Robb MA, Cheeseman JR, Montgomery Jr JA, Vreven T, Kudin KN, Burant JC, Millam JM, Iyengar SS, J. Tomasi, V. Barone, B. Mennucci, M. Cossi, G. Scalmani, N. Rega, G. A. Petersson, H. Nakatsuji, Hada M, Ehara M, Toyota K, Fukuda R, Hasegawa J, Ishida M, Nakajima T, Honda Y, Kitao O, Nakai H, Klene M, Li X, Knox JE, Hratchian HP, Cross JB, Bakken V, Adamo C, Jaramillo J, Gomperts R, Stratmann RE, Yazyev O, Austin AJ, Cammi R, Pomelli C, Ochterski JW, Ayala PY, Morokuma K, Voth GA, Salvador P, Dannenberg JJ, Zakrzewski VG, Dapprich S, Daniels AD, Strain MC, Farkas O, Malick DK, Rabuck AD, Raghavachari K, Foresman JB, Ortiz JV, Cui Q, Baboul AG, Clifford S, Cioslowski J, Stefanov BB, Liu G, Liashenko A, Piskorz P, Komaromi I, Martin RL, Fox DJ, Keith T, Al-Laham MA, Peng CY, Nanayakkara A, Challacombe M, Gill PMW, Johnson B, Chen W, Wong MW, Gonzalez C and Pople JA Gaussian 03, Revision E.01; Gaussian, Inc.: Wallingford CT, 2004. 
62. Tolman, C. A. Steric effects of phosphorus ligands in organometallic chemistry and homogeneous catalysis. Chem. Rev. 1977, 77 (3), 313-348.

63. The $\chi$ values reported in ref. 62 of $\mathrm{PMe}_{2} \mathrm{Ph}$ for $\mathbf{1}, \mathrm{P}(\mathrm{Me})_{3}$ for $\mathbf{2}$, and $\mathrm{P}(\mathrm{OEt})_{3}$ for $\mathbf{3}$ are 9.5 , 7.8 and $20.4 \mathrm{~cm}^{-1}$, respectively.

64. The conversion of $\mathbf{3}$ to $\mathbf{4}$ were confirmed as follows. An NMR tube with a Teflon valve was charged with 3 in $\mathrm{C}_{6} \mathrm{D}_{6}$. The NMR tube was heated at $60{ }^{\circ} \mathrm{C}$ for $2 \mathrm{~h}$, and the sample was measured NMR spectra. Complex 4 and Free $\mathrm{P}(\mathrm{OEt}){ }_{3}$ were observed in ${ }^{1} \mathrm{H}$ and ${ }^{31} \mathrm{P}\left\{{ }^{1} \mathrm{H}\right\} \mathrm{NMR}$ spectra.

65. Therien, M. J.; Trogler, W. C. Tricarbonylbis(phosphine)iron(I) cation radicals - a spectroscopic and theoretical-study. J. Am. Chem. Soc. 1986, 108 (13), 3697-3702.

66. Macneil, J. H.; Chiverton, A. C.; Fortier, S.; Baird, M. C.; Hynes, R. C.; Williams, A. J.; Preston, K. F.; Ziegler, T. An X-ray crystallographic and single-crystal EPR investigation of the cationic, iron-centered radical tricarbonylbis(triphenylphosphine)iron(I), $\left(\mathrm{Fe}(\mathrm{CO})_{3}\left(\mathrm{PPh}_{3}\right)^{2+}\right)-\mathrm{A}$ theoretical-examination of the structural preferences of 5-coordinated 17 -electron complexes. $J$. Am. Chem. Soc. 1991, 113 (26), 9834-9842.

67. Kandler, H.; Gauss, C.; Bidell, W.; Rosenberger, S.; Burgi, T.; Eremenko, I. L.; Veghini, D.; Orama, O.; Burger, P.; Berke, H. The reduction of $\mathrm{Fe}(\mathrm{CO})_{2} \mathrm{~L}_{2} \mathrm{X}_{2}\left(\mathrm{~L}=\mathrm{P}(\mathrm{OMe})_{3}, \mathrm{P}(\mathrm{O} i \mathrm{Pr})_{3}, \mathrm{PEt}_{3}\right.$, $\mathrm{X}=\mathrm{Br}, \mathrm{I})$ - From iron(II) to iron(0) via stable iron(I) intermediates. Chem.-Eur. J. 1995, 1 (8), $541-548$. 
68. Niehaus, T. A.; Hofbeck, T.; Yersin, H. Charge-transfer excited states in phosphorescent organo-transition metal compounds: a difficult case for time dependent density functional theory? RSC Adv. 2015, 5 (78), 63318-63329. 
For Table of Contents Only

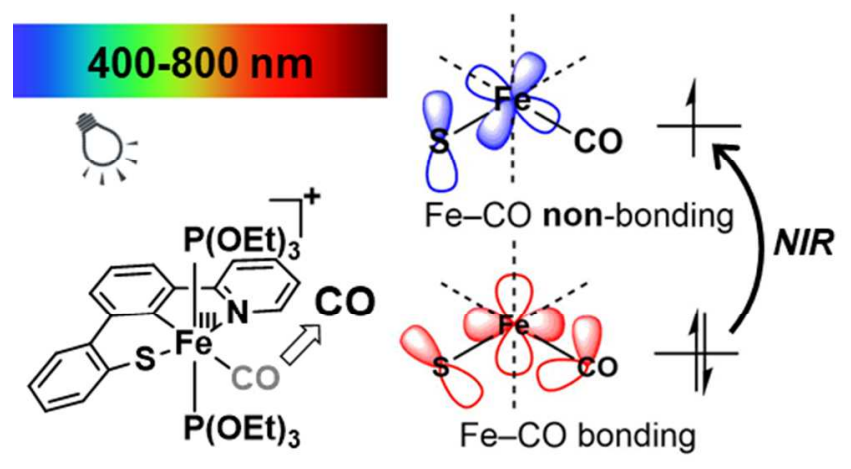

SYNOPSIS

Reasonable sensitivity to the light of biologically transparent wavelength region $(650-1000 \mathrm{~nm})$ is a primary prerequisite of light responsive CO-releasing material applicable to therapeutic use. The newly synthesized iron(III) carbonyl complex, trans-[Fe(L- $\left.\left.\kappa^{3} N, C, S\right)(\mathrm{CO})\left(\mathrm{P}(\mathrm{OEt})_{3}\right)_{2}\right] \mathrm{PF}_{6}$ releases $\mathrm{CO}$ with extensive sensitivity to light including all visible and the above region. A theoretical study with the complex indicates involvement of a peculiar photo-chemistry to depopulate $\mathrm{Fe}-\mathrm{CO}$ bonding orbital. 